\title{
Epidemiological Studies of Pan-Azole Resistant Aspergillus fumigatus Populations Sampled during Tulip Cultivation Show Clonal Expansion with Acquisition of Multi-Fungicide Resistance as Potential Driver
}

\author{
Bart A. Fraaije ${ }^{1,2, * \mathbb{D}}$, Sarah L. Atkins ${ }^{1}$, Ricardo F. Santos ${ }^{3}$, Steven J. Hanley ${ }^{2}$, Jonathan S. West ${ }^{2} \mathbb{D}$ \\ and John A. Lucas ${ }^{2}$ \\ $1 \quad$ NIAB, Cambridge CB3 0LE, UK; sarah.atkins@niab.com \\ 2 Rothamsted Research, Harpenden AL5 2Q, UK; steve.hanley@rothamsted.ac.uk (S.J.H.); \\ jon.west@rothamsted.ac.uk (J.S.W.); john.lucas@rothamsted.ac.uk (J.A.L.) \\ 3 Luiz de Queiroz College of Agriculture, University of São Paulo, Piracicaba 13418-900, SP, Brazil; \\ ricardofelicianodossantos@gmail.com \\ * Correspondence: bart.fraaije@niab.com
}

Citation: Fraaije, B.A.; Atkins, S.L.; Santos, R.F.; Hanley, S.J.; West, J.S.; Lucas, J.A. Epidemiological Studies of Pan-Azole Resistant Aspergillus fumigatus Populations Sampled during Tulip Cultivation Show Clonal Expansion with Acquisition of Multi-Fungicide Resistance as Potential Driver. Microorganisms 2021, 9, 2379. https://doi.org/10.3390/ microorganisms 9112379

Academic Editor: Carla Viegas

Received: 29 October 2021

Accepted: 14 November 2021

Published: 18 November 2021

Publisher's Note: MDPI stays neutral with regard to jurisdictional claims in published maps and institutional affiliations.

Copyright: (c) 2021 by the authors. Licensee MDPI, Basel, Switzerland. This article is an open access article distributed under the terms and conditions of the Creative Commons Attribution (CC BY) license (https:/ / creativecommons.org/licenses/by/ $4.0 /)$.

\begin{abstract}
Pan-azole resistant isolates are found in clinical and environmental Aspergillus fumigatus $(A f)$ populations. Azole resistance can evolve in both settings, with $A f$ directly targeted by antifungals in patients and, in the environment, $A f$ unintendedly exposed to fungicides used for material preservation and plant disease control. Resistance to non-azole fungicides, including methyl benzimidazole carbamates (MBCs), quinone outside inhibitors (QoIs) and succinate dehydrogenase inhibitors (SDHIs), has recently been reported. These fungicide groups are not used in medicine but can play an important role in the further spread of pan-azole resistant genotypes. We investigated the multi-fungicide resistance status and the genetic diversity of $A f$ populations sampled from tulip field soils, tulip peel waste and flower compost heaps using fungicide sensitivity testing and a range of genotyping tools, including STRAf typing and sequencing of fungicide resistant alleles. Two major clones were present in the tulip bulb population. Comparisons with clinical isolates and literature data revealed that several common clonal lineages of $\mathrm{TR}_{34} / \mathrm{L} 98 \mathrm{H}$ and $\mathrm{TR}_{46} / \mathrm{Y} 121 \mathrm{~F} / \mathrm{T} 289 \mathrm{~A}$ strains that have expanded successfully in the environment have also acquired resistance to $\mathrm{MBC}$, QoI and/or SDHI fungicides. Strains carrying multiple fungicide resistant alleles have a competitive advantage in environments where residues of multiple fungicides belonging to different modes of action are present.
\end{abstract}

Keywords: fungicide resistance; azole fungicides; fungicide target proteins; CYP51A; aspergillosis; Aspergillus fumigatus; clonal lineages

\section{Introduction}

Airborne Aspergillus fumigatus (Af) spores can, after inhalation, cause disease in animals and humans ranging from allergic conditions and chronic lung infection to acute invasive aspergillosis (IA). Patients with a weakened immune system are most at risk for IA, and successful therapy depends on early diagnosis and the effective use of antifungals. Due to their efficacy and low toxicity, orally administered azoles have been the drugs of choice, followed by intravenous applications of amphotericin B and echinocandins. However, azole resistance has evolved in $A f$ and is becoming more common in both the clinical setting and the wider environment since the late 1990s [1-3]. Further spread of resistance will have a significant clinical impact as higher mortality rates have already been recorded for patients with voriconazole-resistant IA in comparison with voriconazole-susceptible infection [4]. 
Azoles inhibit the enzyme sterol $14 \alpha$-demethylase (CYP51), a key step in the synthesis of sterols essential for the integrity of cell membranes. Although different azole resistance mechanisms are known [5-7], azole resistance in clinical and environmental $A f$ isolates is mainly associated with alterations in the regulatory and/or coding region of the CYP51A paralogue [8,9]. Azole resistance developed during azole therapy is often associated with single mutations, including G54A/E/RV/W, P216L, M220I/K/L/R/T/V and G448S, conferring different levels of resistance to different azoles. Most highly multi-azole resistant strains found both in clinical settings and the environment belonged to three unique, more complex genotypes- $\mathrm{TR}_{34} / \mathrm{L} 98 \mathrm{H}, \mathrm{TR}_{34} / \mathrm{L} 98 \mathrm{H} / \mathrm{S} 297 \mathrm{~T} / \mathrm{F} 495 \mathrm{I}$ and $\mathrm{TR}_{46} / \mathrm{Y} 121 \mathrm{~F} / \mathrm{T} 289 \mathrm{~A}$. These CYP51A variants are based on a combination of promoter tandem repeat (TR) insert of 34 or $46 \mathrm{bp}$ with mutations resulting in amino acid substitutions L98H, Y121F, S297T, T289A and F495I. Isolates carrying $\mathrm{TR}_{34} / \mathrm{L} 98 \mathrm{H}$ have been found in Europe since 1998 [10]. TR $_{34} /$ L98H/S297T/F495I, first detected in the Netherlands in 1998 [2], is often found in Asia [11,12], whereas the first TR $\mathrm{TR}_{46} / \mathrm{Y} 121 \mathrm{~F} / \mathrm{T} 289 \mathrm{~A}$ isolate was reported from North America in 2008 [13]. More complex CYP51A variants have recently emerged, including $\mathrm{TR}_{34} / \mathrm{L} 98 \mathrm{H} / \mathrm{T} 289 \mathrm{~A} / \mathrm{I} 364 \mathrm{~V} / \mathrm{G} 448 \mathrm{~S}, \mathrm{TR}_{46} / \mathrm{Y} 121 \mathrm{~F} / \mathrm{T} 289 \mathrm{~A} / \mathrm{S} 363 \mathrm{P} / \mathrm{I} 364 \mathrm{~V} / \mathrm{G} 448 \mathrm{~S}$ and different $\mathrm{TR}_{46}$ variants $\left(\mathrm{TR}_{46}{ }^{2}, \mathrm{TR}_{46}{ }^{3}\right.$ and $\left.\mathrm{TR}_{46}{ }^{4}\right)$ in combination with $\mathrm{Y} 121 \mathrm{~F}, \mathrm{M} 172 \mathrm{~V}$, T289A and G448S [14-17].

Recent studies have shown that several $\mathrm{TR}_{34}$ - and $\mathrm{TR}_{46}$-based CYP51A variants have evolved resistance to non-azole fungicides belonging to different modes of action that are not used in medicine [17-19]. These fungicides, methyl benzimidazole carbamates (MBC), quinone outside inhibitors (QoI) and succinate dehydrogenase inhibitors (SDHI), targeting $\beta$-tubulin (cytoskeleton), cytochrome $b$ (respiration) and succinate dehydrogenase (respiration), respectively, are commonly used to control plant diseases and resistance development in $A f$ is an unintended side effect as agronomically used azole fungicides are not directly targeted against $A f$. Although $\mathrm{TR}_{34} / \mathrm{TR}_{46}$-based CYP51A have been associated with the environmental route of resistance development rather than the patient route, the origin of these strains without additional CYP51A mutations remains unclear and an initial selection in the clinical setting with subsequent spread through aerosols into the wider environment cannot be excluded [20,21]. However, fungicide resistance can evolve in the environment and measures should be taken to prevent further spread to retain the effectiveness of the azole class for both environmental and medical applications [22].

Research is ongoing to determine the hotspots for resistance development and spread. Tulip bulbs have previously been identified as a vehicle for international spread of azole resistant $A f$ isolates [23,24]. Decaying flower bulb waste from farms, industrial wood-chip waste, and industrial green-waste storage, able to support the growth and reproduction of $A f$ in the presence of fungicides, have already been identified as hotspots [25]. A better understanding on the emergence and spatiotemporal spread of different fungicide resistant alleles can improve our understanding on hotspots for fungicide resistance development and aid development of measures to reduce exposure risk.

The aim of this study was to investigate the resistance status of $A f$ populations sampled from tulip field soils, tulip bulbs, tulip peel waste piles and flower compost heaps to azole, MBC, QoI and SDHI fungicides. A panel of clinical isolates and a set of environmental isolates, that were characterized in a previous study [17], were also included to compare the fungicide sensitivity phenotypes and genotypes. Sequencing of genes encoding fungicide target proteins, cell surface protein (CSP) and mating type, as well as microsatellite typing based on short tandem repeats (STR $A f$ ) was carried out for all strains to identify genetical relatedness and to check for clonal expansion [26,27]. The spread of clonal lineages in both the environment and the clinical setting is further discussed using data that can be found in the literature or the available AfumID database [28]. 


\section{Materials and Methods}

\subsection{Sampling and Strain Isolation}

In total, 32 samples, ranging from tulip field soils (soil not in close contact with bulbs was sampled), flower bulbs, tulip peel waste heaps (decaying material) and flower waste compost sites were studied (Table 1). Soils from six tulip fields at five locations were sampled to a depth of $8 \mathrm{~cm}$ at three sampling points, separated five meters apart during summer in 2016.

Table 1. Collected samples with their locations.

\begin{tabular}{|c|c|c|}
\hline Sample $^{1}$ & Origin and Year & $\begin{array}{l}\text { Frequency of } \\
\text { Azole Resistant } \\
\text { Isolates }^{2}\end{array}$ \\
\hline Soil tulip field 1 & Biddinghuizen, NL (2016) & $0 / 30$ \\
\hline Soil tulip field 2 & Dronten, NL (2016) & $1 / 30$ \\
\hline Soil tulip field 3 & Venhuizen, NL (2016) & $1 / 30$ \\
\hline Soil tulip field 4 & Westwoud, NL (2016) & $0 / 30$ \\
\hline Soil tulip field 5 & Westwoud, NL (2016) & $5 / 30$ \\
\hline Soil tulip field 6 & Zyperdijk, NL (2016) & $3 / 30$ \\
\hline Bulbs 1 Tulipa 'Stresa' & Noordwijkerhout, NL (2015) & $4 / 10$ \\
\hline Bulbs 2 Tulipa 'Apeldoorn Yellow' & Vaassen, NL (2015) & $4 / 10$ \\
\hline Bulbs 3 Tulipa greigii 'Roodkapje' & Vaassen, NL (2015) & $4 / 10$ \\
\hline Bulbs 4 Tulipa 'Praestans Shogun' & Vaassen, NL (2015) & $3 / 10$ \\
\hline Bulbs 5 Tulipa 'Claudia' & Noordwijkerhout, NL (2015) & $6 / 10$ \\
\hline Bulbs 6 Tulipa 'Triumph Hotpants' & Millbrook, UK (2015) & $1 / 8$ \\
\hline Bulbs 7 Tulipa 'Mickey Mouse' & Canterbury, UK (2015) & $1 / 10$ \\
\hline Bulbs 8 Tulipa 'Gavota' & Wickford, UK (2015) & $0 / 10$ \\
\hline Bulbs 9 Tulipa 'Guiseppi Verdi' & Horsham, UK (2015) & $0 / 10$ \\
\hline Bulbs 10 Tulipa 'White Marvel' & Preston, UK (2015) & $1 / 10$ \\
\hline Bulbs 11 Tulipa 'Red Impression' & Hillegom, NL (2015) & $1 / 10$ \\
\hline Bulbs 12 Tulipa 'Negrita' & Vaassen, NL (2017) & $0 / 10$ \\
\hline Bulbs 13 Tulipa 'Rembrand' & Vaassen, NL (2017) & $0 / 10$ \\
\hline Bulbs 14 Narcissus 'Pink Pride' & Vaassen, NL (2017) & $0 / 10$ \\
\hline Bulbs 15 Narcissus 'Jetfire' & Vaassen, NL (2017) & $0 / 10$ \\
\hline Bulbs 16 Narcissus mix & Hillegom, NL (2017) & $0 / 10$ \\
\hline Bulb peel waste heap tulip grower 1 & NL (2018) & $6 / 11$ \\
\hline Bulb peel waste heap tulip grower 2 & NL (2018) & $1 / 1$ \\
\hline Bulb peel waste heap tulip grower 3 & NL (2018) & $1 / 2$ \\
\hline Bulb peel waste heap tulip grower 4 & NL (2018) & $3 / 4$ \\
\hline Bulb peel waste heap tulip grower 5 & NL (2018) & $11 / 19$ \\
\hline Bulb peel waste heap tulip grower 6 & NL (2018) & $1 / 5$ \\
\hline Compost heap tulip grower A & NL (2018) & $8 / 8$ \\
\hline Compost heap tulip grower B & NL (2018) & $1 / 1$ \\
\hline Compost heap tulip grower $\mathrm{C}$ & NL (2018) & $10 / 10$ \\
\hline
\end{tabular}

${ }^{1}$ Isolates were obtained from colonies growing on Sabouraud Dextrose agar plates without fungicides with exception of the compost heap isolates that were picked from plates amended with $5 \mu \mathrm{g} / \mathrm{mL}$ tebuconazole.

${ }^{2}$ Azole resistant isolates have at least two raised MIC values for either voriconazole $(>1.0 \mu \mathrm{g} / \mathrm{mL})$, imazalil $(>2.0 \mu \mathrm{g} / \mathrm{mL})$ and / or tebuconazole $(>4.0 \mu \mathrm{g} / \mathrm{mL})$.

Materials from tulip peel waste heaps and compost sites were sampled and sent in by commercial tulip growers during August 2018. For both soil, bulb peel waste heap and compost samples, $2 \mathrm{~g}$ aliquots of material were added to $8 \mathrm{~mL}$ of phosphate buffered saline amended with $0.1 \%(v / v)$ Tween 20 (PBST) and $A f$ strains isolated as described in our previous study [17]. Tulip and daffodil bulbs were purchased directly from garden centers or ordered on-line from nurseries in the autumn during 2016-2018. The outer skin of ten bulbs per sample was peeled off, pooled, and further processed using $25 \mathrm{~mL}$ of PBST. To grow and isolate $A f$ colonies aliquots of the buffer extracts were plated out on untreated, or azole fungicide ( $5 \mu \mathrm{g} / \mathrm{mL}$ tebuconazole) amended Sabouraud dextrose (SD) agar (Oxoid Ltd., Basingstoke, UK) containing penicillin $(100 \mathrm{U} / \mathrm{mL})$ and streptomycin $(100 \mu \mathrm{g} / \mathrm{mL})$ and incubated for 2 days at $48{ }^{\circ} \mathrm{C}$. 


\subsection{Panel of Clinical Isolates}

A study of a panel of $20 \mathrm{Af}$ clinical strains, which included 18 azole-insensitive and two reference strains (AF65 (National Collection of Pathogenic Fungi (NCPF) 7097)) and AF293 (NCPF 77367)), all isolated before 2018, was also caried out to allow comparisons of the fungicide sensitivity pheno- and genotypes found in the clinical setting and in the environment. The isolates originated from Belgium (CYP_15_2, 15_7, 15_38, 15_46, 15_63 and 15_80), Germany (Asp 164, 168, 251 and 267), Japan (OKH50 (2016)), Taiwan (D007), the Netherlands (ARAF013, ARAF017, V093-26 (2010) and V094-54 (2009) and the UK (AF65 (1997), AF293 (1993), CXH_06 and 07).

\subsection{Fungicide Sensitivity Testing}

After subculturing single colonies in tissue culture flasks with $12 \mathrm{~mL} \mathrm{SD}$ agar for seven days at $37^{\circ} \mathrm{C}$, spores were harvested through shaking with $5 \mathrm{~mm}$ glass beads after addition of $3 \mathrm{~mL}$ of saline. Spore suspensions containing approximately $10^{6}$ spores $/ \mathrm{mL}$ in sterile distilled water were used in the microprocessor controlled Autoplate Spiral Plating System AP5000 (Advanced Instruments, Norwood, MA, USA) according to the manufacturer's instructions as described previously [17]. Depending on the molecular weight of the compounds, an up to a 200-fold fungicide dilution gradient on SD agar was achieved using $15 \mathrm{~cm}$ plates. The concentration ranges $(\mu \mathrm{g} / \mathrm{mL})$ for the different fungicides were: boscalid (0.1-18.469), carbendazim (0.1-11.464), imazalil (0.25-43.153), itraconazole (0.025-6.113 or 0.1-22.324), posaconazole $(0.005-1.0)$ (pyraclostrobin $(0.1-20.120)$, tebuconazole (0.1-17.349), terbinafine (0.01-1.7) and voriconazole (0.1-19.120). The different concentration ranges were chosen to distinguish sensitive wild-type (wt) isolates without known resistance mechanisms from those of insensitive isolates harboring resistance mechanism(s) in a single assay. Isolates were streaked on the spiral SD agar plates (eight per plate) from the outside to the center using cotton swaps and incubated at $37^{\circ} \mathrm{C}$ in the dark. After $24 \mathrm{~h}$ incubation, the fungal growth of each isolate on the spiral plate was visually assessed and MIC values determined using the Spiral Gradient Endpoint (SGE) software.

\subsection{DNA Extractions}

After harvesting spores from one-week cultures in tissue culture flasks, $1.5 \mathrm{~mL}$ of spore suspensions was transferred into a $2 \mathrm{~mL}$ tube and centrifuged for $2 \mathrm{~min}$ at 13,200 rpm. After removing the supernatant, DNA was extracted according to the MasterPure Yeast DNA Purification kit (Lucigen Corporation, Madison, WI, USA) with the inclusion of an extra bead-beating step, which involved the addition of glass beads $(0.425-0.600 \mathrm{~mm})$ and the use of the Genie 2 Vortex (Scientific Industries, Bohemia, NY, USA) at full power for $2 \mathrm{~min}$. This step was carried out after the lysis step just before adding the MPC Protein Precipitation Reagent.

\subsection{PCR Amplification and Sequencing of Fungicide Resistant Alleles}

Whole or partial fungicide target genes ( $\beta$-tubulin, cytochrome $b$ and succinate hydrogenase subunit $\mathrm{B}$ ), covering all regions where mutations affecting inhibitor binding have been reported for fungi, were amplified with PCR, sequenced, and analyzed using Geneious software version 10.0 (Biomatters, Auckland, New Zealand) according to the previously established protocols [17].

\subsection{Cell Surface Protein Typing}

The cell surface protein (CSP) (XM_749624.1) encoding gene of $A f$ was also partially sequenced from selected strains [29]. CSP typing of strains, including CSP t02* or t02B [17], was carried out according to the established nomenclature [26], which is based on the tandem repeat region, in which up to ten different 12-bp repeat sequences have been found in different copy numbers, and the flanking regions. After manual alignment of sequences, a phylogenetic tree for the different CSP sequences encountered in this study 
was constructed using the Geneious Tree Builder software (Biomatters, Auckland, New Zealand) based on the Tamura-Nei distance model and the Neighbor-Joining method.

\subsection{Microsatellite Typing Based on Short Tandem Repeats in A. fumigatus (STRAf)}

In total, $128 A f$ isolates with different levels of azole sensitivity from this study and our previous studies on environmental and reference isolates were further characterized using microsatellite genotyping based on a panel of nine short tandem repeat markers (STRAf 2A, 2B, 2C, 3A, 3B, 3C, 4A, 4B and 4C) according to the method previously described and validated [27,30]. GenAlEx v.6.503 software was used to identify distinct multi-locus genotypes (MLGs), where a single difference in an allele size was considered enough to discriminate a unique MLG [31]. To visualize the phylogenetic relationships among MLGs, a minimum spanning network (MSN) was generated using the R package poppr v.2.8.3 [32], which is based on Bruvo's distance [33].

\section{Results}

\subsection{Isolation and Fungicide Sensitivity Testing of A. fumigatus Isolates from Tulip Field Soils}

In total, 180 isolates were isolated from soils sampled from six fields at five different locations (Table 1). Figures 1 and 2 show the sensitivity profiles for the overall population to eight different fungicides.

The frequency of pan-azole resistant isolates within this population varied between $0 \%$ and $16.7 \%$ per field $(n=30)$ with an average overall frequency of $5.6 \%$ (10 out of 180) (Table 1). Amongst the 10 pan-azole resistant isolates, three isolates from these (STNL5-B7, STNL5-C1 and STNL5-C8), all isolated from tulip field 5 (Table 1), carried $\mathrm{TR}_{46} / \mathrm{Y} 121 \mathrm{~F} / \mathrm{T} 289 \mathrm{~A}$ and showed high levels of insensitivity to all azoles, itraconazole $(>22.324 \mu \mathrm{g} / \mathrm{mL})$, voriconazole $(>19.120 \mu \mathrm{g} / \mathrm{mL})$, posaconazole $(>0.200 \mu \mathrm{g} / \mathrm{mL})$, imazalil $(>15.0 \mu \mathrm{g} / \mathrm{mL})$ and tebuconazole $(>17.349 \mu \mathrm{g} / \mathrm{mL})$, carbendazim $(>11.464 \mu \mathrm{g} / \mathrm{mL})$ and pyraclostrobin $(>20.120 \mu \mathrm{g} / \mathrm{mL})$. Six out of seven isolates, showing lower levels of insensitivity to most of the azoles tested, carried TR 34 /L98H. Four of these (STNL2-B8, STNL5-B6, STNL6-A3 and STNL6-B2) were sensitive to both carbendazim and pyraclostrobin (MIC values below $3.0 \mu \mathrm{g} / \mathrm{mL}$ ), while STNL3-C8 was highly insensitive to pyraclostrobin but not carbendazim, and STNL6-B1 highly insensitive to both carbendazim and pyraclostrobin. The remaining isolate, STNL5-C5, with low levels of insensitivity to multiple azoles carried $\mathrm{TR}_{34} / \mathrm{L} 98 \mathrm{H} / \mathrm{S} 297 \mathrm{~T} / \mathrm{F} 495 \mathrm{I}$ and was also insensitive to carbendazim.

Only one azole sensitive strain, STNL1-A8 with wild-type CYP51A, was resistant to carbendazim. Several strains showing low levels of insensitivity to tebuconazole, in particular, carried F46Y/M172V /E427K. Amongst these strains, STNL2-C9 showed a raised MIC value of $6.017 \mu \mathrm{g} / \mathrm{mL}$ to pyraclostrobin. As expected, only small differences in sensitivity to terbinafine, a squalene epoxidase inhibitor, were measured for all isolates and this was not linked to a CYP51A variant. Of the medical azoles tested, posaconazole was most effective with the majority of isolates displaying MICs between 0.007 and $0.046 \mu \mathrm{g} / \mathrm{mL}$, followed by voriconazole (most strains in MIC range 0.100 to $0.657 \mu \mathrm{g} / \mathrm{mL}$ ), imazalil (most strains in MIC range 0.250 to $1.643 \mu \mathrm{g} / \mathrm{mL}$ ), tebuconazole (most strains in MIC range 0.110 to $1.710 \mu \mathrm{g} / \mathrm{mL}$ ) and itraconazole (most strains in MIC range 0.403 to $1.774 \mu \mathrm{g} / \mathrm{mL}$ ), respectively (Figure 1). A wide range of sensitivities were measured for itraconazole with a large fraction of isolates $(n=33)$, the majority carrying wild-type CYP51A alleles, having MIC values exceeding $10.000 \mu \mathrm{g} / \mathrm{mL}$. 

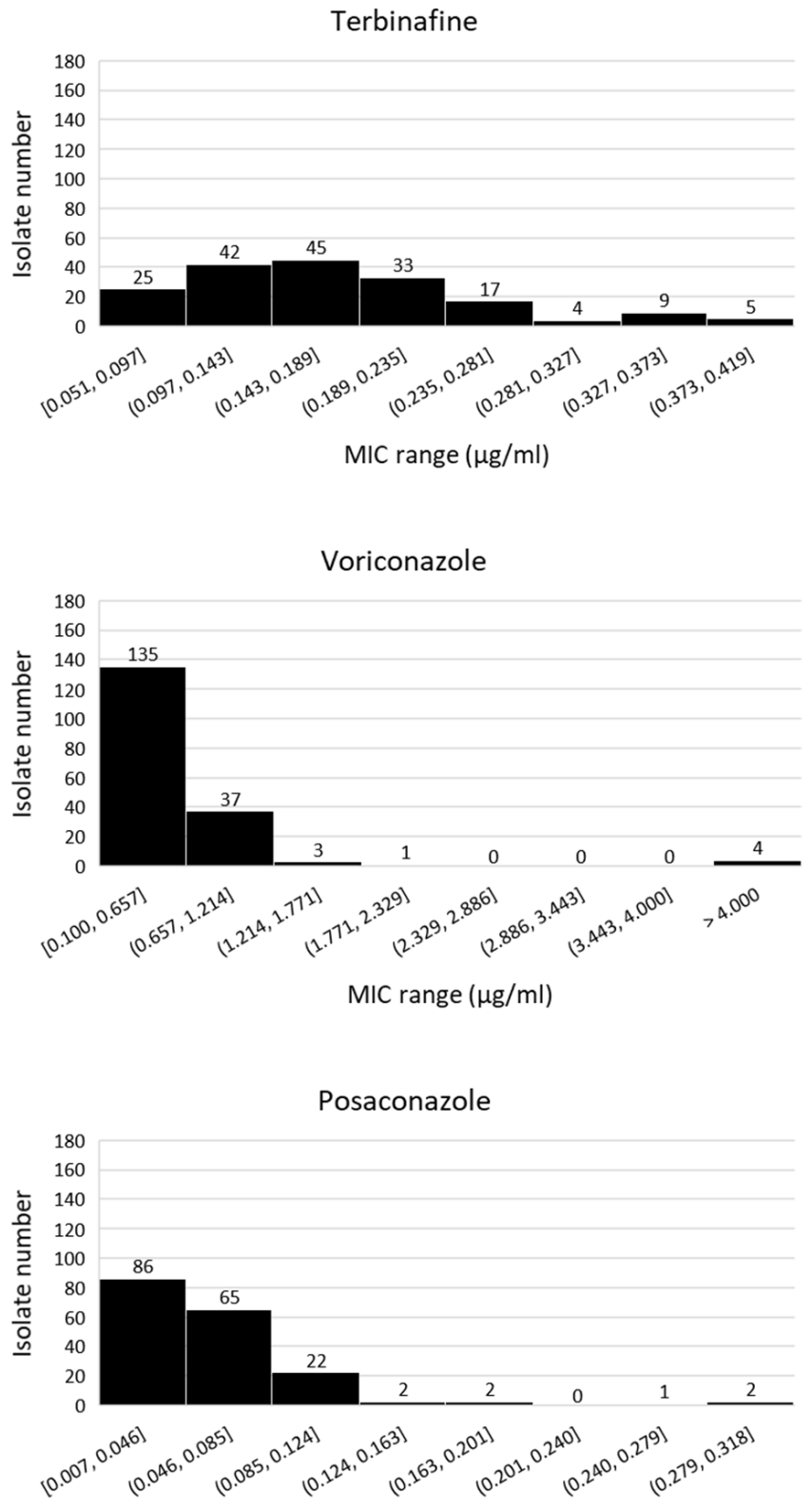

$\mathrm{MIC}$ range $(\mu \mathrm{g} / \mathrm{ml})$

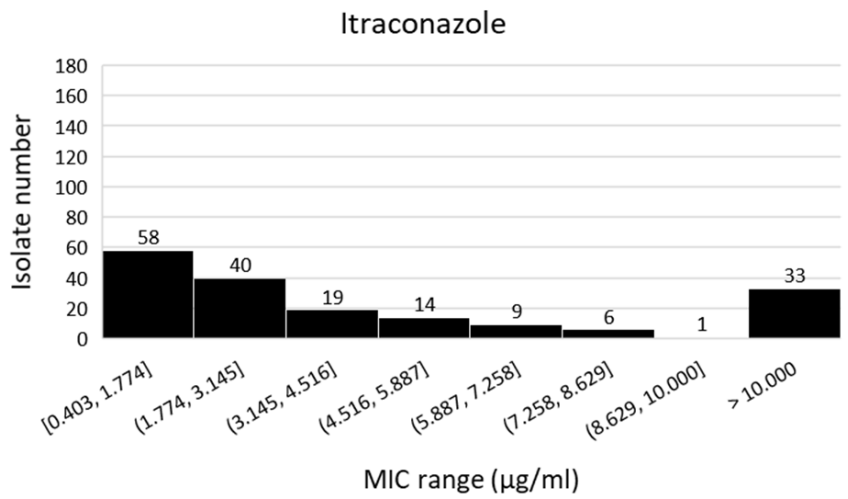

Figure 1. Cont. 

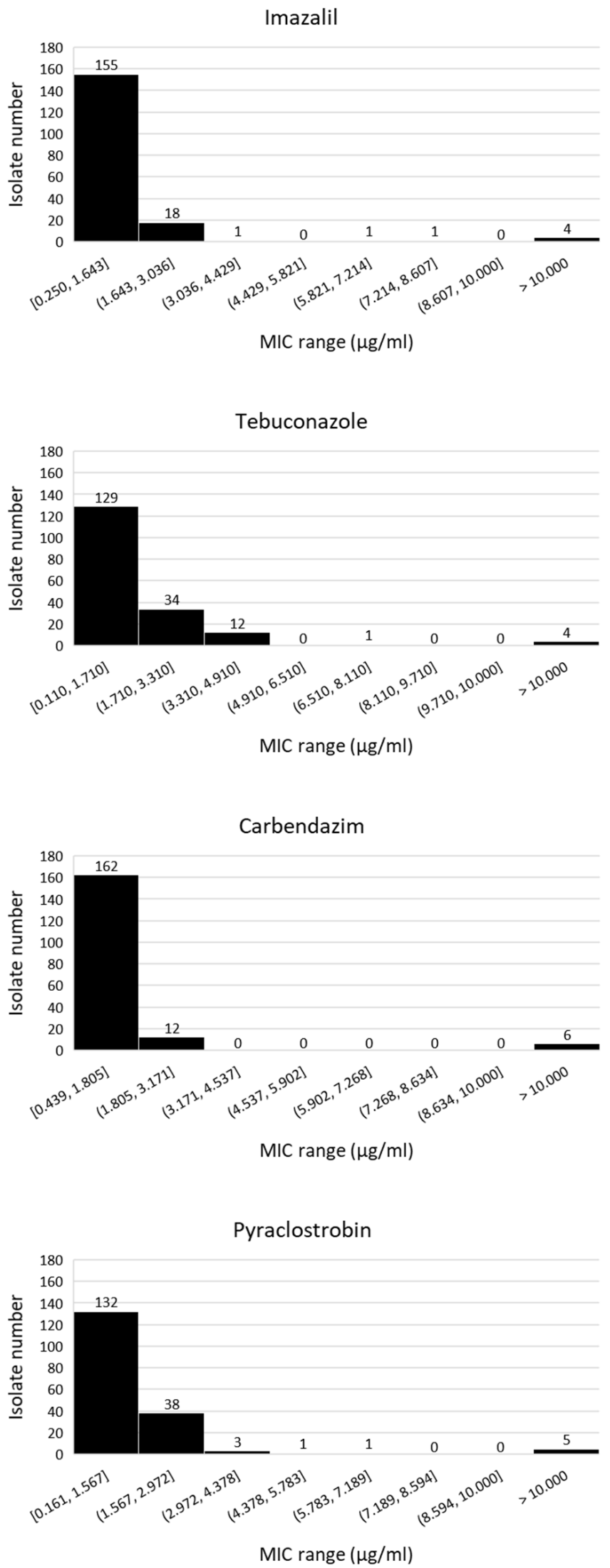

Figure 1. MIC distribution of $A$. fumigatus isolates sampled from tulip field soils $(n=180)$ in the Netherlands. Numbers show amount (sum) of isolates within each MIC range. 


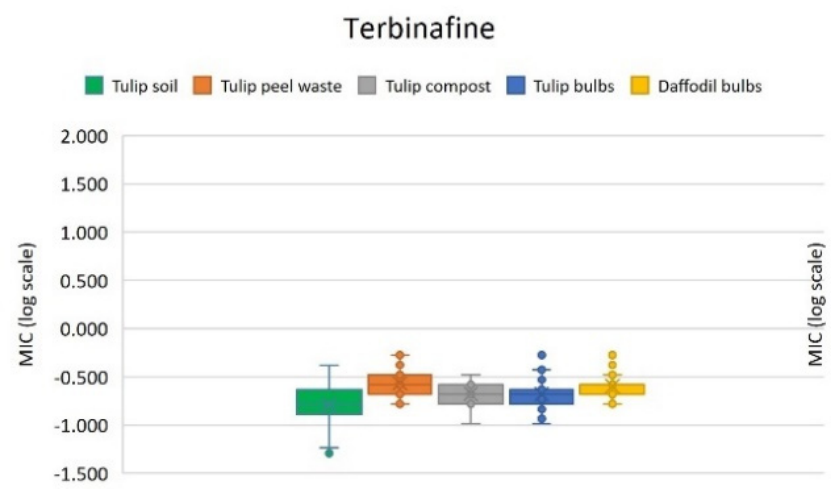

Carbendazim

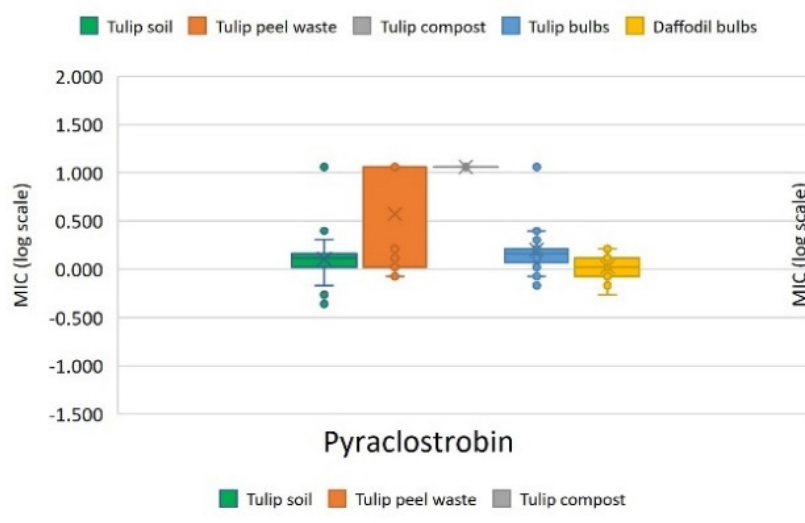

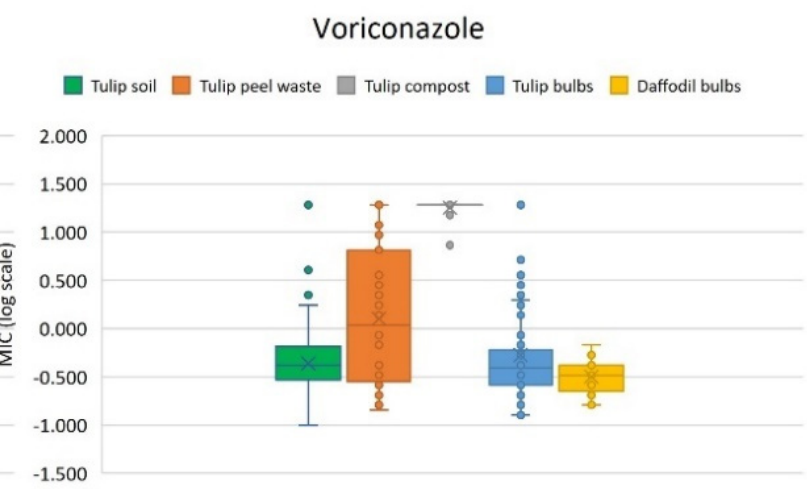

Tebuconazole

$\square$ Tulip soil $\square$ Tulip peel waste $\square$ Tulip compost $\square$ Tulip bulbs $\square$ Daffodil bulbs

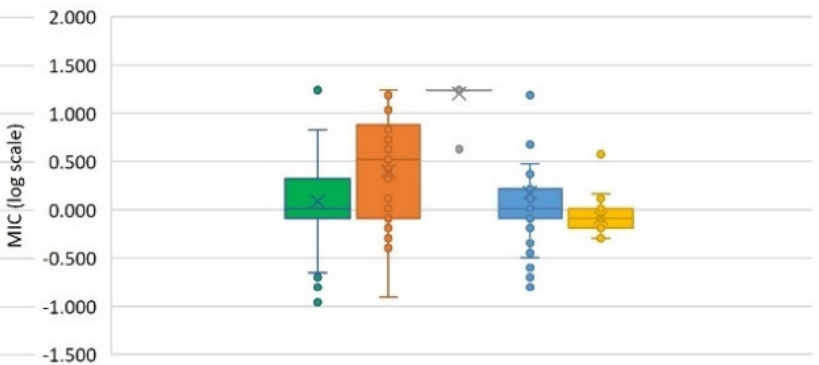

Imazalil

Tulip soil $\square$ Tulip peel waste $\square$ Tulip compost $\square$ Tulip bulbs $\square$ Daffodil bulbs

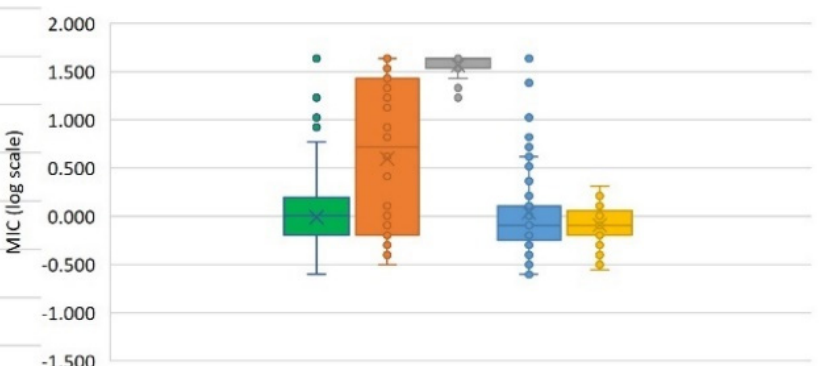

Figure 2. Comparison of fungicide sensitivity levels for strains isolated from tulip field soils $(n=180)$, tulip peel waste $(n=42)$, tulip compost $(n=19)$ and flower bulbs (tulips $(n=128)$ and daffodils $(n=30)$ ). For voriconazole, tebuconazole and carbendazim out of range values spiral plating MIC values were displayed as the log values of 19.120, 17.349 and $11.464 \mu \mathrm{g} / \mathrm{mL}$, respectively.

3.2. Isolation and Fungicide Sensitivity Testing of A. fumigatus Isolates from Flower Bulbs, Tulip Peel Waste Heaps and Compost

In total, 200 strains were isolated from tulip bulbs $(n=128)$, daffodil bulbs $(n=30)$ and tulip peel waste $(n=42)$ on SD agar without addition of tebuconazole and 19 strains from compost $(n=19)$ on tebuconazole-amended SD agar (Table 1$)$. Eight additional strains were also isolated from three different tulip peel waste samples using tebuconazole-amended SD agar. The results of the fungicide sensitivity tests for the four largest populations together with the tulip soil population are displayed in Figure 2, while test results for a selection of individual strains are shown in Table 2. 
Table 2. Sensitivity of environmental Aspergillus fumigatus isolates to a panel of fungicides belonging to different modes of action and their further characterization using CSP, mating type and CYP51A variant analysis. Isolates ranked according to voriconazole sensitivity (low to high MIC values in $\mu \mathrm{g} / \mathrm{mL}$ ).

\begin{tabular}{|c|c|c|c|c|c|c|c|c|c|}
\hline Isolate & CYP51A & VRC & IMA & TEB & CAR & PYR & BOS & CSP & $\begin{array}{c}\text { Mating } \\
\text { Type }\end{array}$ \\
\hline STNL1-A8 & WT & 0.292 & 0.714 & 0.814 & $>11.464$ & 1.110 & - & t04A & MAT1-1 \\
\hline T8-2 & WT & 0.471 & 0.803 & 0.643 & 1.169 & 0.872 & 0.253 & $\mathrm{t} 11$ & MAT1-1 \\
\hline STNL5-C5 & $\mathrm{TR}_{34} / \mathrm{L} 98 \mathrm{H} / \mathrm{S} 297 \mathrm{~T} / \mathrm{F} 495 \mathrm{I}$ & 0.531 & 8.367 & 4.227 & $>11.464$ & 0.685 & 0.199 & $\mathrm{t} 02$ & MAT1-2 \\
\hline T6-3 & $\mathrm{TR}_{34} / \mathrm{L} 98 \mathrm{H}$ & 0.675 & 5.236 & $>17.349$ & 2.013 & 0.477 & - & $\mathrm{t} 11$ & MAT1-1 \\
\hline STNL2-C9 & F46Y/M172V/E427K & 0.760 & 1.443 & 2.970 & 0.843 & 6.017 & - & $\mathrm{t} 02 \mathrm{~B}$ & MAT1-1 \\
\hline STNL3-C8 & $\mathrm{TR}_{34} / \mathrm{L} 98 \mathrm{H}$ & 0.857 & 1.283 & 4.227 & 1.303 & $>20.120$ & - & t04B & MAT1-1 \\
\hline TP UT1A-2 & $\mathrm{TR}_{34} / \mathrm{L} 98 \mathrm{H}$ & 0.857 & 8.367 & 5.348 & $>11.464$ & $>20.120$ & 0.253 & $\mathrm{t} 02$ & MAT1-2 \\
\hline STNL6-B2 & $\mathrm{TR}_{34} / \mathrm{L} 98 \mathrm{H}$ & 1.381 & 2.592 & 4.227 & 1.169 & 0.538 & 0.157 & - & MAT1-1 \\
\hline STNL6-A3 & $\mathrm{TR}_{34} / \mathrm{L} 98 \mathrm{H}$ & 1.381 & 3.277 & 6.768 & 1.303 & 0.538 & 0.199 & t01 & MAT1-2 \\
\hline T3-6 & $\mathrm{TR}_{34} / \mathrm{L} 98 \mathrm{H}$ & 1.381 & 6.619 & $>17.349$ & 2.013 & 1.110 & 0.253 & $\mathrm{t} 11$ & MAT1-1 \\
\hline TP UT1B-1 & $\mathrm{TR}_{34} / \mathrm{L} 98 \mathrm{H}$ & 1.754 & 6.619 & $>17.349$ & $>11.464$ & $>20.120$ & 0.517 & $\mathrm{t} 11$ & MAT1-1 \\
\hline TP UT5C-5 & $\mathrm{TR}_{34} / \mathrm{L} 98 \mathrm{H}$ & 1.754 & 6.619 & 4.227 & 0.679 & $>20.12$ & 0.224 & $\mathrm{t} 02$ & MAT1-2 \\
\hline STNL2-B8 & $\mathrm{TR}_{34} / \mathrm{L} 98 \mathrm{H}$ & 1.754 & 10.577 & 4.227 & 2.013 & 0.294 & 0.321 & t04B & MAT1-1 \\
\hline STNL5-B6 & $\mathrm{TR}_{34} / \mathrm{L} 98 \mathrm{H}$ & 2.227 & 1.622 & 3.341 & 1.619 & 0.872 & 0.321 & $\mathrm{t} 11$ & MAT1-2 \\
\hline T2-1 & $\mathrm{TR}_{34} / \mathrm{L} 98 \mathrm{H}$ & 2.227 & 4.142 & $>17.349$ & 1.619 & 1.110 & 0.321 & $\mathrm{t} 11$ & MAT1-1 \\
\hline STNL6-B1 & $\mathrm{TR}_{34} / \mathrm{L} 98 \mathrm{H}$ & 4.047 & 5.887 & $>17.349$ & $>11.464$ & $>20.120$ & $>18.469$ & t01 & MAT1-2 \\
\hline T11-8 & $\mathrm{TR}_{34} / \mathrm{L} 98 \mathrm{H}$ & 5.139 & 10.577 & $>17.349$ & $>11.464$ & $>20.120$ & 0.517 & t02 & MAT1-1 \\
\hline STNL5-B7 & $\mathrm{TR}_{46} / \mathrm{Y} 121 \mathrm{~F} / \mathrm{T} 289 \mathrm{~A}$ & $>19.120$ & 16.901 & $>17.349$ & $>11.464$ & $>20.120$ & 0.157 & t02 & MAT1-1 \\
\hline T7-9 & $\mathrm{TR}_{46} / \mathrm{Y} 121 \mathrm{~F} / \mathrm{T} 289 \mathrm{~A}$ & $>19.120$ & 24.020 & $>17.349$ & $>11.464$ & $>20.120$ & - & $\mathrm{t} 01$ & MAT1-1 \\
\hline TP UT4A-1 & $\mathrm{TR}_{46} / \mathrm{Y} 121 \mathrm{~F} / \mathrm{T} 289 \mathrm{~A}$ & $>19.120$ & 34.138 & $>17.349$ & $>11.464$ & $>20.120$ & 0.407 & t01 & - \\
\hline STNL5-C1 & $\mathrm{TR}_{46} / \mathrm{Y} 121 \mathrm{~F} / \mathrm{T} 289 \mathrm{~A}$ & $>19.120$ & $>43.153$ & $>17.349$ & $>11.464$ & $>20.120$ & 0.177 & t06A & MAT1-1 \\
\hline STNL5-C8 & $\mathrm{TR}_{46} / \mathrm{Y} 121 \mathrm{~F} / \mathrm{T} 289 \mathrm{~A}$ & $>19.120$ & $>43.153$ & $>17.349$ & $>11.464$ & $>20.120$ & 0.199 & - & MAT1-2 \\
\hline T3-5 & $\mathrm{TR}_{46} / \mathrm{Y} 121 \mathrm{~F} / \mathrm{T} 289 \mathrm{~A}$ & $>19.120$ & $>43.153$ & $>17.349$ & $>11.464$ & $>20.120$ & - & $\mathrm{t} 01$ & MAT1-1 \\
\hline T4-9 & $\mathrm{TR}_{46} / \mathrm{Y} 121 \mathrm{~F} / \mathrm{T} 289 \mathrm{~A}$ & $>19.120$ & $>43.153$ & $>17.349$ & $>11.464$ & $>20.120$ & - & t01 & MAT1-1 \\
\hline T4-10 & $\mathrm{TR}_{46} / \mathrm{Y} 121 \mathrm{~F} / \mathrm{T} 289 \mathrm{~A}$ & $>19.120$ & $>43.153$ & $>17.349$ & $>11.464$ & $>20.120$ & - & t01 & MAT1-1 \\
\hline T5-1 & $\mathrm{TR}_{46} / \mathrm{Y} 121 \mathrm{~F} / \mathrm{T} 289 \mathrm{~A}$ & $>19.120$ & $>43.153$ & $>17.349$ & $>11.464$ & $>20.120$ & 0.285 & $\mathrm{t} 01$ & MAT1-1 \\
\hline T5-2 & $\mathrm{TR}_{46} / \mathrm{Y} 121 \mathrm{~F} / \mathrm{T} 289 \mathrm{~A}$ & $>19.120$ & $>43.153$ & $>17.349$ & $>11.464$ & $>20.120$ & - & $\mathrm{t} 01$ & MAT1-1 \\
\hline T5-5 & $\mathrm{TR}_{46} / \mathrm{Y} 121 \mathrm{~F} / \mathrm{T} 289 \mathrm{~A}$ & $>19.120$ & $>43.153$ & $>17.349$ & $>11.464$ & $>20.120$ & - & $\mathrm{t} 01$ & MAT1-1 \\
\hline TP TEB5C-2 & $\mathrm{TR}_{34} / \mathrm{L} 98 \mathrm{H} / \mathrm{T} 289 \mathrm{~A} / \mathrm{I} 364 \mathrm{~V} / \mathrm{G} 448 \mathrm{~S}$ & $>19.120$ & $>43.153$ & $>17.349$ & $>11.464$ & $>20.120$ & 0.321 & $\mathrm{t} 02$ & MAT1-2 \\
\hline TC TEB6B-1 & $\mathrm{TR}_{34} / \mathrm{L} 98 \mathrm{H} / \mathrm{T} 289 \mathrm{~A} / \mathrm{I} 364 \mathrm{~V} / \mathrm{G} 448 \mathrm{~S}$ & $>19.120$ & $>43.153$ & $>17.349$ & $>11.464$ & $>20.120$ & $>18.469$ & $\mathrm{t} 02$ & MAT1-2 \\
\hline
\end{tabular}

VRC (voriconazole), IMA (imazalil) and TEB (tebuconazole) are azoles, inhibiting 14 $\alpha$-demethylase (sterol biosynthesis); CAR (carbendazim) is a MBC fungicide, inhibiting $\beta$-tubulin assembly (cytoskeleton); PYR (pyraclostrobin) is a QoI fungicide, inhibiting respiration (complex III); BOS (boscalid) is a SDHI fungicide, inhibiting respiration (complex II); -, not determined.

As expected, 19 compost isolates (Table 1), all isolated from tebuconazole-amended SD agar, showed high levels of insensitivity to all azoles tested, with 18,17 and 14 of these also having MIC values exceeding 17.349, 19.120 and $43.153 \mu \mathrm{g} / \mathrm{mL}$, for tebuconazole, voriconazole and imazalil, respectively (Figure 2). All 19 isolates were also highly insensitive to both carbendazim and pyraclostrobin having MIC values greater than 11.464 and $20.120 \mu \mathrm{g} / \mathrm{mL}$, respectively.

Tulip peel waste heaps also contained high frequencies of multi-fungicide insensitive isolates, with 23 out of 42 strains tested insensitive to multiple azoles and pyraclostrobin, respectively (Figure 2). Of these, 22 were also highly insensitive to carbendazim. Six out of 23 were highly insensitive to voriconazole, tebuconazole and imazalil showing MICs greater than $10 \mathrm{ppm}$ (including TP UT4A-1 and TP UT4B-2), while the remaining isolates (including TP UT1B-1, TP UT1A-2 and TP UT5C-5), showed raised levels of insensitivity to one or more azoles. All 19 isolates that were sensitive to pyraclostrobin were also sensitive to all azoles tested with MICs lower than 1.0, 2.0 and $4.0 \mu \mathrm{g} / \mathrm{mL}$ for voriconazole, imazalil and tebuconazole, respectively. All eight strains isolated from tebuconazole-amended SD agar were insensitive to both carbendazim and pyraclostrobin and showed high levels of insensitivity to multiple azoles (including TP TEB5C-5).

The frequency of multi-fungicide resistant isolates was much lower for the sampled population from tulip bulbs (Figure 2). Only eight out of 128 isolates were highly insensitive to carbendazim, of which seven (T3-5, T4-9, T4-10, T5-1, T5-2, T5-5 and T7-9) were also highly insensitive to voriconazole, tebuconazole and imazalil, showing MICs greater than $10 \mu \mathrm{g} / \mathrm{mL}$. Reduced sensitivity to two or more azoles (MICs exceeding 1.0, 2.0 and $4.0 \mathrm{\mu g} / \mathrm{mL}$ for voriconazole, imazalil and tebuconazole, respectively) were measured for 
the other carbendazim insensitive isolate (T11-8) and 17 additional isolates (including T2-1, T3-6 and T6-3). None of the strains isolated from daffodil bulbs showed any levels of insensitivity to carbendazim, voriconazole and tebuconazole while only one isolate tested positive for imazalil, with a MIC of $2.051 \mu \mathrm{g} / \mathrm{mL}$ just above the discriminatory dose of $2.0 \mu \mathrm{g} / \mathrm{mL}$.

3.3. Azole Resistance Phenotype-to-Genotype Relationship, Cell Surface Protein and Mating Typing of A. fumigatus Isolates from the Environment with a Focus on Tulip Cultivation

A selection of 30 environmental $A f$ isolates with different levels of insensitivity to azoles, carbendazim and/or pyraclostrobin were further tested for sensitivity to boscalid and were further characterized by determination of CSP, mating type and fungicide resistant alleles (Table 2).

Isolates carrying $\mathrm{TR}_{46} / \mathrm{Y} 121 \mathrm{~F} / \mathrm{T} 289 \mathrm{~A}$, frequently detected in this study, and $\mathrm{TR}_{34} /$ $\mathrm{L98H} / \mathrm{T} 289 \mathrm{~A} / \mathrm{I} 364 \mathrm{~V} / \mathrm{G} 448 \mathrm{~S}$, only detected in two strains isolated from tulip peel waste (TP TEB5C-5) and tulip compost (TC TEB6B-1) on tebuconazole-amended SD agar were highly insensitive to all azoles tested, with high MIC values greater than or equal to 19.120, 17.349 and $16.901 \mu \mathrm{g} / \mathrm{mL}$ measured for voriconazole, tebuconazole and imazalil, respectively (Table 2). Isolates carrying $\mathrm{TR}_{34} / \mathrm{L} 98 \mathrm{H}$ showed lower levels of azole insensitivity to voriconazole and imazalil, but six out of 13 were also highly insensitive to tebuconazole (MIC values > $17.349 \mu \mathrm{g} / \mathrm{mL}$ ). STNL5-C5, carrying TR 34 /L98H/S297T/F495I showed a low level of insensitivity to voriconazole and tebuconazole, but its insensitivity to imazalil (MIC value of $8.367 \mu \mathrm{g} / \mathrm{mL}$ ) was high in comparison to most $\mathrm{TR}_{34} / \mathrm{L} 98 \mathrm{H}$ isolates. Isolate STNL2-C9, carrying F46Y/M172V/E427K, showed only slightly raised MIC values for voriconazole, imazalil and tebuconazole in comparison with wild-type CYP51A strains.

All $\mathrm{TR}_{46} / \mathrm{Y} 121 \mathrm{~F} / \mathrm{T} 289 \mathrm{~A}$ and $\mathrm{TR}_{34} / \mathrm{L} 98 \mathrm{H} / \mathrm{T} 289 \mathrm{~A} / \mathrm{I} 364 \mathrm{~V} / \mathrm{G} 448 \mathrm{~S}$ isolates, as well as four out of $13 \mathrm{TR}_{34} / \mathrm{L} 98 \mathrm{H}$ isolates tested, were also insensitive to both carbendazim (MIC values $>11.464 \mu \mathrm{g} / \mathrm{mL}$ ) and pyraclostrobin (MIC values $>20.120 \mu \mathrm{g} / \mathrm{mL}$ ). Insensitivity to carbendazim but not to pyraclostrobin was also measured for STNL1-A8 and STNL5-C5, carrying wild-type CYP51A and $\mathrm{TR}_{34}$ /L98H/S297T/F495I, respectively. Sensitivity to carbendazim and a moderate level of pyraclostrobin insensitivity (MIC value of $6.017 \mu \mathrm{g} / \mathrm{mL}$ ) was measured for isolate STNL2-C9, carrying F46Y /M172V/E427K. High levels of insensitivity to pyraclostrobin but not to carbendazim were measured for $\mathrm{TR}_{34} / \mathrm{L} 98 \mathrm{H}$ isolates STNL3-C8 and TP UT5C-5. Resistance to boscalid (MIC values $>18.469 \mu \mathrm{g} / \mathrm{mL}$ ) was found in two isolates with high insensitivity to the different azoles, carbendazim and pyraclostrobin, being STNL6-B1 and TC TEB6B-1 carrying $\mathrm{TR}_{34} / \mathrm{L} 98 \mathrm{H}$ and $\mathrm{TR}_{34} / \mathrm{L} 98 \mathrm{H} / \mathrm{T} 289 \mathrm{~A} /$ $\mathrm{I} 364 \mathrm{~V} / \mathrm{G} 448 \mathrm{~S}$, respectively.

$\beta$-tubulin sequence analysis revealed that insensitivity to carbendazim was conferred in all environmental isolates by the amino acid substitution F200Y (codon change TTC to TAC). Isolate STNL5-C5, carrying TR $_{34}$ /L98H/S297T/F495I, showed a double nucleotide change resulting in F200Y (TTC to TAT). High levels of pyraclostrobin insensitivity (MIC values $>20.120 \mu \mathrm{g} / \mathrm{mL}$ ) were associated with the cytochrome $b$ alteration G143A (GGT to GCT), whereas the lower level of insensitivity to pyraclostrobin (MIC value of $6.017 \mu \mathrm{g} / \mathrm{mL}$ ) in isolate STNL2-C9 was linked to cytochrome $b$ F129L (TTC to TTA). Insensitivity to boscalid was conferred by SdhB alteration H270Y (CAC to TAC) in STNL6-B1 and TC TEB6B-1.

Multiple CSP and mating types were found in both $\mathrm{TR}_{46} / \mathrm{Y} 121 \mathrm{~F} / \mathrm{T} 289 \mathrm{~A}$ (CSP t01, 02 and $\mathrm{t} 06 \mathrm{~A}$ ) and $\mathrm{TR}_{34} / \mathrm{L98H}$ isolates (CSP t01, t02, t04B and t11). CSP t02 and t02B were detected in STNL5-C5 (TR 34 /L98H/S297T/F495I) and STNL2-C9 (F46Y/M172V/E427K), respectively, whereas both $\mathrm{TR}_{34} / \mathrm{L} 98 \mathrm{H} / \mathrm{T} 289 \mathrm{~A} / \mathrm{I} 364 \mathrm{~V} / \mathrm{G} 448 \mathrm{~S}$ isolates carried CSP t02 and MAT1-2.

\subsection{Azole Resistance Phenotype-to-Genotype Relationship, Cell Surface Protein and Mating Typing of A. fumigatus Isolates from the Clinical Setting}

Results for the panel of 20 clinical Af isolates, including AF65 and AF293 as reference isolates, are presented in Table 3. The order of the voriconazole sensitivity mirrored the results for the environmental isoles with the reference isolates AF65 (wild-type CYP51A) 
and AF293 (F46Y/M172V / N284T/D255E/E427K) most sensitive, followed by isolates carrying $\mathrm{TR}_{34} / \mathrm{L} 98 \mathrm{H} / \mathrm{S} 297 \mathrm{~T} / \mathrm{F} 495 \mathrm{I}, \mathrm{TR}_{34} / \mathrm{L} 98 \mathrm{H}$ and $\mathrm{TR}_{46} / \mathrm{Y} 121 \mathrm{~F} / \mathrm{T} 289 \mathrm{~A}$, respectively. With regard to imazalil, four isolates with $\mathrm{TR}_{34} / \mathrm{L} 98 \mathrm{H} / \mathrm{S} 297 \mathrm{~T} / \mathrm{F} 495 \mathrm{I}$ showed a higher level of insensitivity, approximately three-fold, than most $\mathrm{TR}_{34} / \mathrm{L} 98 \mathrm{H}$ isolates. In comparison with the MIC value of the wild-type isolate AF65, the average MIC value of the $\mathrm{TR}_{34} / \mathrm{L} 98 \mathrm{H} / \mathrm{S} 297 \mathrm{~T} / \mathrm{F} 495 \mathrm{I}$ isolates was approximately 15-fold higher (Resistance Factor (RF) of 15). TR $\mathrm{TR}_{46} / \mathrm{Y} 121 \mathrm{~F} / \mathrm{T} 289 \mathrm{~A}$ were most insensitive, with $\mathrm{RF}>25 . \mathrm{TR}_{34} / \mathrm{L} 98 \mathrm{H}$ and $\mathrm{TR}_{34} / \mathrm{L} 98 \mathrm{H} / \mathrm{S} 297 \mathrm{~T} / \mathrm{F} 495 \mathrm{I}$ isolates showed different levels of insensitivity to tebuconazole (MIC values ranging from 3.341 to $>17.349 \mu \mathrm{g} / \mathrm{mL}$ ) with several strains also highly insensitive to carbendazim (MIC values $>11.464 \mu \mathrm{g} / \mathrm{mL}$ ). Two $\mathrm{TR}_{34} / \mathrm{L} 98 \mathrm{H}$ isolates, ARAF017 and CYP_15_46, were insensitive to fungicides belonging to all four different modes of action (azoles, MBC and QoI and SDHI fungicides). All six TR $\mathrm{TR}_{46} / \mathrm{Y} 121 \mathrm{~F} / \mathrm{T} 289 \mathrm{~A}$ isolates showed high levels of insensitivity to tebuconazole and were also higly insensitive to both carbendazim (MIC values $>11.464 \mu \mathrm{g} / \mathrm{mL}$ ) and pyraclostrobin (MIC values $>20.120 \mu \mathrm{g} / \mathrm{mL}$ ). One isolate, CYP_15_46, was also insensitive to boscalid (MIC value $>18.469 \mu \mathrm{g} / \mathrm{mL}$ ).

Table 3. Sensitivity of clinical Aspergillus fumigatus isolates to a panel of fungicides belonging to different modes of action and their further characterization using CSP, mating type and CYP51A variant analysis. Isolates ranked according to voriconazole sensitivity (low to high MIC values in $\mu \mathrm{g} / \mathrm{mL}$ ).

\begin{tabular}{|c|c|c|c|c|c|c|c|c|c|}
\hline Isolate & CYP51A & VOR & IMA & TEB & CAR & PYR & BOS & CSP & $\begin{array}{c}\text { Mating } \\
\text { Type }\end{array}$ \\
\hline AF65 & WT & 0.329 & 1.141 & 0.814 & 1.619 & 1.413 & 0.157 & t02 & MAT1-2 \\
\hline AF293 & F46Y/M172V/N284T/D255E/E427K & 0.531 & 2.915 & 1.649 & 1.303 & 0.538 & - & t06A & MAT1-2 \\
\hline ARAF013 & $\mathrm{TR}_{34} / \mathrm{L} 98 \mathrm{H} / \mathrm{S} 297 \mathrm{~T} / \mathrm{F} 495 \mathrm{I}$ & 0.760 & 13.370 & 4.227 & $>11.464$ & 0.332 & 0.253 & $\mathrm{t} 11$ & MAT1-2 \\
\hline Asp 251 & $\mathrm{TR}_{34} / \mathrm{L} 98 \mathrm{H} / \mathrm{S} 297 \mathrm{~T} / \mathrm{F} 495 \mathrm{I}$ & 1.088 & 19.002 & 5.348 & $>11.464$ & 1.413 & 0.157 & $\mathrm{t} 02$ & MAT1-1 \\
\hline CYP_15_63 & $\mathrm{TR}_{34} / \mathrm{L} 98 \mathrm{H} / \mathrm{S} 297 \mathrm{~T} / \mathrm{F} 495 \mathrm{I}$ & 1.088 & 13.370 & 6.768 & $>11.464$ & 1.110 & 1.702 & t01 & MAT1-1 \\
\hline D007 & $\mathrm{TR}_{34} / \mathrm{L} 98 \mathrm{H} / \mathrm{S} 297 \mathrm{~T} / \mathrm{F} 495 \mathrm{I}$ & 1.088 & 15.032 & 3.341 & 0.843 & 0.100 & 0.285 & $\mathrm{t} 04 \mathrm{~A}$ & MAT1-1 \\
\hline CXH_07 & $\mathrm{TR}_{34} / \mathrm{L} 98 \mathrm{H}$ & 1.381 & 5.887 & 6.768 & 1.303 & 0.332 & 0.199 & t04A & MAT1-1 \\
\hline Asp 267 & $\mathrm{TR}_{34} / \mathrm{L} 98 \mathrm{H}$ & 1.381 & 4.142 & 4.227 & 1.619 & 0.161 & 0.157 & $\mathrm{t} 11$ & MAT1-2 \\
\hline CXH_06 & $\mathrm{TR}_{34} / \mathrm{L} 98 \mathrm{H}$ & 1.557 & 5.236 & 8.563 & 1.303 & 0.423 & 0.321 & t04B & MAT1-2 \\
\hline Asp 164 & $\mathrm{TR}_{34} / \mathrm{L} 98 \mathrm{H}$ & 1.976 & 6.619 & 6.768 & 1.619 & 1.110 & 0.224 & $\mathrm{t} 11$ & MAT1-2 \\
\hline Asp 168 & $\mathrm{TR}_{34} / \mathrm{L} 98 \mathrm{H}$ & 1.976 & 5.236 & 8.563 & 2.013 & 0.607 & 0.199 & t04B & MAT1-2 \\
\hline OKH50 & $\mathrm{TR}_{34} / \mathrm{L} 98 \mathrm{H}$ & 2.227 & 4.142 & 5.348 & 0.757 & 0.332 & 0.407 & t02 & MAT1-2 \\
\hline ARAF017 & $\mathrm{TR}_{34} / \mathrm{L} 98 \mathrm{H}$ & 4.560 & 13.370 & $>17.349$ & $>11.464$ & $>20.12$ & $>18.469$ & $\mathrm{t} 04 \mathrm{~A}$ & MAT1-2 \\
\hline CYP_15_46 & $\mathrm{TR}_{34} / \mathrm{L} 98 \mathrm{H}$ & 5.791 & 8.367 & 13.711 & $>11.464$ & $>20.12$ & $>18.469$ & t02 & MAT1-1 \\
\hline CYP_15_80 & $\mathrm{TR}_{46} / \mathrm{Y} 121 \mathrm{~F} / \mathrm{T} 289 \mathrm{~A}$ & 9.338 & $>43.153$ & 8.563 & $>11.464$ & $>20.12$ & 0.199 & $\mathrm{t} 02$ & MAT1-1 \\
\hline CYP_15_2 & $\mathrm{TR}_{46} / \mathrm{Y} 121 \mathrm{~F} / \mathrm{T} 289 \mathrm{~A}$ & $>19.12$ & $>43.153$ & 13.711 & $>11.464$ & $>20.12$ & 0.253 & $\mathrm{t} 01$ & MAT1-2 \\
\hline CYP_15_7 & $\mathrm{TR}_{46} / \mathrm{Y} 121 \mathrm{~F} / \mathrm{T} 289 \mathrm{~A}$ & $>19.12$ & $>43.153$ & $>17.349$ & $>11.464$ & $>20.12$ & 0.253 & $\mathrm{t} 01$ & MAT1-2 \\
\hline CYP_15_38 & $\mathrm{TR}_{46} / \mathrm{Y} 121 \mathrm{~F} / \mathrm{T} 289 \mathrm{~A}$ & $>19.12$ & $>43.153$ & $>17.349$ & $>11.464$ & $>20.12$ & $>18.469$ & t09 & MAT1-2 \\
\hline V093-26 & $\mathrm{TR}_{46} / \mathrm{Y} 121 \mathrm{~F} / \mathrm{T} 289 \mathrm{~A}$ & $>19.12$ & 27.006 & 8.563 & $>11.464$ & $>20.12$ & 0.517 & t01 & MAT1-2 \\
\hline V094-54 & $\mathrm{TR}_{46} / \mathrm{Y} 121 \mathrm{~F} / \mathrm{T} 289 \mathrm{~A}$ & $>19.12$ & $>43.153$ & $>17.349$ & $>11.464$ & $>20.12$ & 0.285 & $\mathrm{t} 01$ & MAT1-2 \\
\hline
\end{tabular}

VRC (voriconazole), IMA (imazalil) and TEB (tebuconazole) are azoles, inhibiting 14 $\alpha$-demethylase (sterol biosynthesis); CAR (carbendazim) is a MBC fungicide, inhibiting $\beta$-tubulin assembly (cytoskeleton); PYR (pyraclostrobin) is a QoI fungicide, inhibiting respiration (complex III); BOS (boscalid) is a SDHI fungicide, inhibiting respiration (complex II); -, not determined.

$\beta$-tubulin sequence analysis revealed that insensitivity to carbendazim was conferred in all but one isolate by the amino acid substitution F200Y (codon change TTC to TAC). Carbendazim insensitivity in isolate CYP_15_46 was conferred by the beta-tubulin alteration E198A (GAG to GCG). Like the enviromental strains, mutations resulting in cytochrome $b$ G143A (GGT to GCT) and SdhB H270Y (CAC to $\underline{T} A C)$ were found in all isolates insensitive to carbendazim and pyraclostrobin, respectively.

Multiple CSP and mating types were found in TR $46 / \mathrm{Y} 121 \mathrm{~F} / \mathrm{T} 289 \mathrm{~A}$ (CSP t01, t02 and t09), $\mathrm{TR}_{34}$ /L98H isolates (CSP t02, t04A, t04B and t11) and $\mathrm{TR}_{34} / \mathrm{L} 98 \mathrm{H} / \mathrm{S} 297 \mathrm{~T} / \mathrm{F} 495 \mathrm{I}(\mathrm{CSP}$ $\mathrm{t} 01, \mathrm{t} 02, \mathrm{t} 04 \mathrm{~A}$ and $\mathrm{t} 11$ ).

3.5. Genetic Diversity of Azole-Resistant Aspergillus fumigatus Isolated from the Clinical Setting and the Wider Environment with a Focus on Tulip Cultivation

In total, 128 Af isolates were analysed using STRAf typing. These originated from air $(n=5)$ and arable soils $(n=43)$ as part of our previous studies, and from tulip field soils 
( $n=13)$, tulip bulbs $(n=29)$, tulip peel waste $(n=13)$, tulip compost $(n=1)$ and patients $(n=18)$ as described here. Six reference strains that were used in both studies were also included. Most isolates were also further characterised with CSP and mating gene typing as well as CYP51A sequence analysis (see Table S1 for details). The STRAf profile for tulip compost isolate TC TEB6B-1 was inconclusive, showing two different product sizes for six out of the nine loci, indicative of a mixed culture, and was excluded for further analysis. Among 127 isolates, 99 distinct unique multilocus genotypes (MLGs) were identified, of which 88 were represented by single isolates (Figure 3).

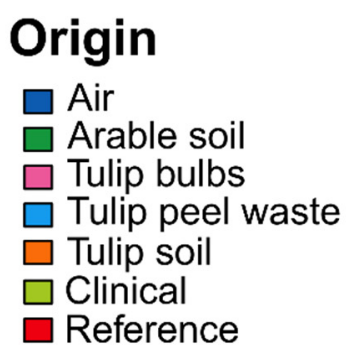

Strain/node<smiles>[O][C]1CCCCC1</smiles><smiles>O</smiles>
0

01<smiles>CCC</smiles>

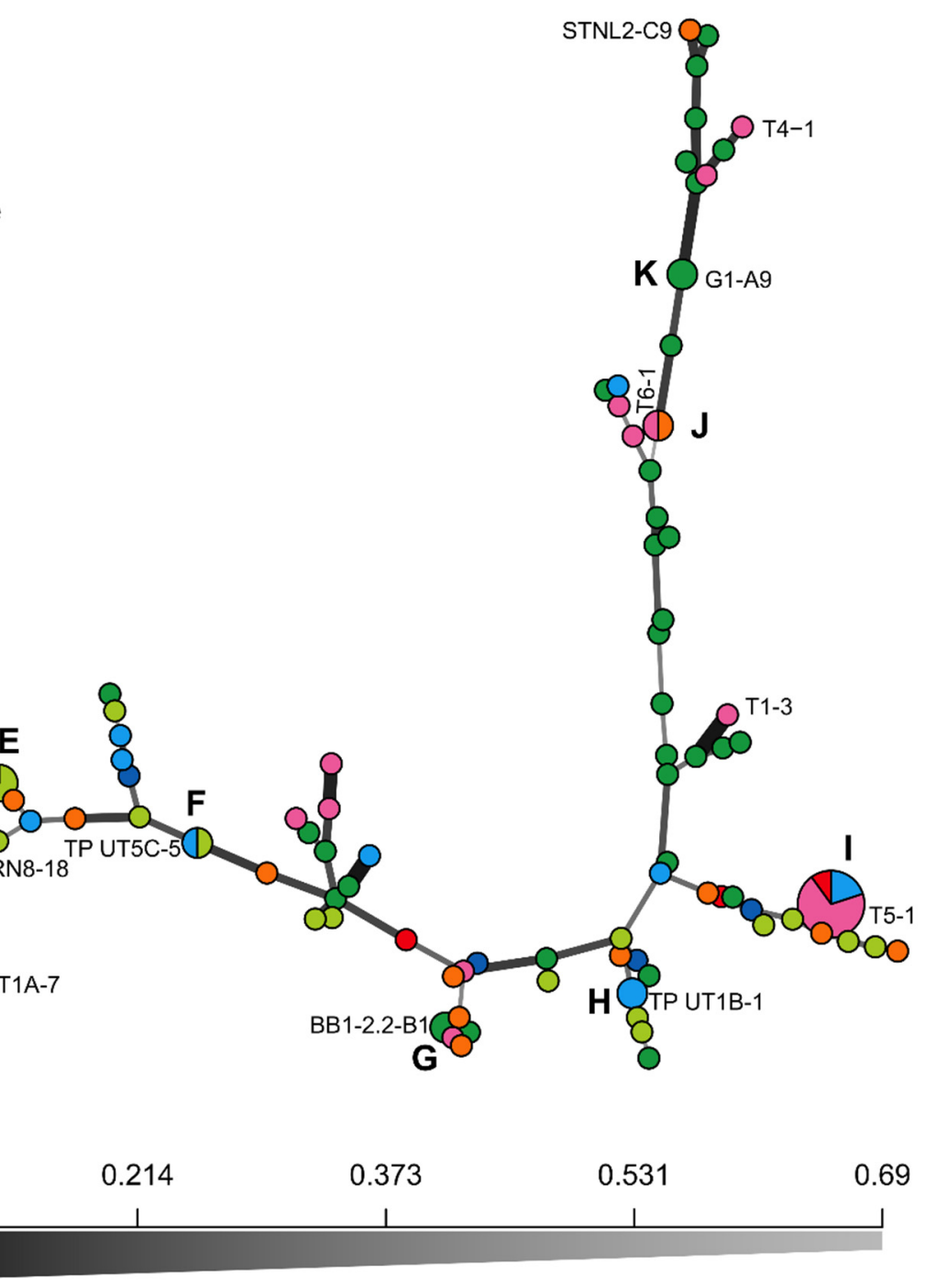

\section{Bruvo's distance}

Figure 3. Minimum-spanning networks showing the genetic relationship of Aspergillus fumigatus multilocus genotypes (MLGs) originating from different sources. The relatedness between MLGs is based on Bruvo's genetic distances, which accounts for the stepwise mutation of microsatellite loci. Each node represents an MLG with one or more individuals. Nodes with multiple isolates (clonal lineages), clusters, are arranged alphabetically. Nodes that are more closely related have darker and thicker edges, whereas nodes that are more distantly related have lighter and thinner edges. Names of a selection of isolates, including all medical strains, are also displayed and all details on strains can be found in Table S1.

Eleven MLGs were detected in multiple strains (clusters A to K), which can be regarded as clonal lineages. Cluster I was the largest cluster with ten isolates, all carrying $\mathrm{TR}_{46} / \mathrm{Y} 121 \mathrm{~F} / \mathrm{T} 289 \mathrm{~A}, \mathrm{CSP}$ t01 and MAT1-1, and insensitive to both carbendazim and pyraclostrobin (Table 2). This cluster included seven strains isolated from tulip bulbs originating from the Netherlands and the UK (T3-5, T4-9, T4-10, T5-1, T5-2, T5-5 and T7-9), two strains 
from tulip waste heaps (including TP UT4A-1) and reference strain, TR46-NL, isolated from the environment in the Netherlands and tested previously [17]. Cluster $C$ consisted of nine isolates carrying $\mathrm{TR}_{34} / \mathrm{L} 98 \mathrm{H}, \mathrm{CSP}$ t11 and MAT1-1, with no insensitivity observed for carbendazim and pyraclostrobin. Eight isolates originated from multiple tulip bulb samples obtained in both the Netherlands and the UK (T1-2, T2-1, T3-3, T3-6, T4-7, T5-3, T6-3 and T10-5) and a soil isolate, SS8-7A, originating from a sugar beet field in Belgium in our previous study [17]. Cluster D contained two reference strains (TR34-NL and 08-19-02-10, isolated in the Netherlands in 2008) and arable soil isolate RN8-18, carrying TR $34 / \mathrm{L} 98 \mathrm{H}$, CSP t04B and MAT1-2, all showing sensitivity to carbendazim and pyraclostrobin in our previous study [17]. Cluster E is formed by two clinical strains, CYP_15_7 and V093-54, from Belgium and the Netherlands, respectively, and STNL5-C8, a Dutch tulip field soil isolate, all carrying $\mathrm{TR}_{46} / \mathrm{Y} 121 \mathrm{~F} / \mathrm{T} 289 \mathrm{~A}, \mathrm{CSP}$ t01 and MAT1-2, all showing insensitivity to both carbendazim and pyraclostrobin. The remaining clusters contained two isolates. Cluster F contained strain TP UT5C-5, isolated from a tulip peel waste heap sample, and clinical strain OKH50 isolated in Japan in 2016 [34], both carrying $\mathrm{TR}_{34} / \mathrm{L} 98 \mathrm{H}, \mathrm{CSP}$ t02 and MAT1-2. Both isolates were sensitive to carbendazim, but only TP UT5C-5 was insensitive to pyraclostrobin. Two tulip waste heap isolates, including TP UT1B-1, formed cluster $\mathrm{H}$, both carrying $\mathrm{TR}_{34} / \mathrm{L} 98 \mathrm{H}, \mathrm{CSP}$ t11 and MAT1-1, and insensitive to carbendazim and pyraclostrobin. Clusters J and K are formed by F46Y/M172V/E427K isolates with low levels of insensitivity to azoles detected previously (ref) and carried combinations of CSP t13 with MAT1-2 and CSP t02B with MAT1-1, respectively. All F46Y/M172V/E427K isolates grouped together in the upper right branch positioned above cluster J in Figure 3. With the exception of isolate STNL2-C9, no insensitivity to fungicides other than azoles have been detected in isolates carrying F46Y/M172V/E427K. The remaining clusters, A, B and $\mathrm{G}$, were formed by wild-type CYP51A isolates carrying CSP t04A with MAT1-1, CSP t01 with MAT1-1, and t18A with MAT1-1, respectively, and all showing sensitivity to all fungicides tested.

\section{Discussion}

Tulip bulbs have previously been identified as a vehicle for the international spread of azole resistant $A f$ isolates [23,24], and decaying flower bulb waste from farms has already been identified as a hotspot in a previous study [25]. However, little is known about the emergence and spatiotemporal spread of different fungicide resistant alleles belonging to different modes of action, such as MBC, QoI and SDHI fungicides [17], in this environment. In this study, we sampled $A f$ populations from tulip field soils, tulip bulbs, tulip peel waste heaps and tulip grower compost and compared their fungicide sensitivity status to both azole and non-azole fungicides. A selection of fungicide insensitive isolates associated with tulip cultivation and a panel of medical isolates were further characterized for presence of fungicide resistant alleles and genotyped using CSP and STRAf typing [26,27]. Several clones were identified and the level of clonal expansion of pan-azole and non-azole resistant strains in both the clinical setting and the wider environment is also further discussed hereinafter.

The 5.6\% frequency (ten out of 180 isolates) of pan-azole insensitive $A f$ strains isolated from Dutch tulip field soils in 2016 (Table 1) was higher than the reported 0.5\% (two out 428 isolates) measured for arable soils sampled at nine different locations in France, Germany, and the UK in 2015 using the same sampling and test procedures [17]. Three out of the ten pan-azole insensitive isolates, all sampled from the same tulip field carried $\mathrm{TR}_{46} / \mathrm{Y121F} / \mathrm{T} 289 \mathrm{~A}$, while six $\mathrm{TR}_{34} / \mathrm{L} 98 \mathrm{H}$ and one $\mathrm{TR}_{34} / \mathrm{L} 98 \mathrm{H} / \mathrm{S} 297 \mathrm{~T} / \mathrm{F} 495 \mathrm{I}$ strain were identified as well. One $\mathrm{TR}_{34} / \mathrm{L} 98 \mathrm{H}$, STNL6-B1, and all three $\mathrm{TR}_{46} / \mathrm{Y121F} / \mathrm{T} 289 \mathrm{~A}$ isolates, STNL5-B7, STNL5-C1 and STNL5-C7, were also insensitive to both the MBC fungicide carbendazim and the QoI fungicide pyraclostrobin (Table 2) which was attributed to alterations in $\beta$-tubulin (F200Y) and cytochrome $b$ (G143A), respectively, as previously reported [17]. One of the $\mathrm{TR}_{46} / \mathrm{Y} 121 \mathrm{~F} / \mathrm{T} 289 \mathrm{~A}$ strains, STNL5-C8, shared a MLG (26-21-933-11-22-8-14-10) with clinical isolates from the Netherlands and environmental isolates 
from India and Tanzania [35,36]. Interestingly, STNL6-B1 was also insensitive to the SDHI fungicide boscalid and carried the SdhB alteration H270Y, a change associated with SDHI resistance [17]. The $\mathrm{TR}_{34} / \mathrm{L} 98 \mathrm{H} / \mathrm{S} 297 \mathrm{~T} / \mathrm{F} 495 \mathrm{I}$ isolate, STNL5-C5, was also insensitive to carbendazim and showed a double mutation resulting in the F200Y $\beta$-tubulin alteration. One F46Y / M172V /E427K isolate, STNL2-C9, showing low levels of insensitivity to azoles, was also moderately insensitive to pyraclostrobin (MIC value of $6.017 \mu \mathrm{g} / \mathrm{mL}$ ) and carried cytochrome $b$ F129L, an alteration well known to confer low to moderate levels of QoI resistance in plant pathogenic fungi [37], and recently also reported for $A f$ [19]. Only one azole sensitive strain, STNL1-A8, carrying wild-type CYP51A appeared to have evolved carbendazim insensitivity by acquiring the beta-tubulin F200Y allele, which has been reported once before [19]. Azole resistance seems to have spread quickly after the emergence of $\mathrm{TR}_{34}$ - and $\mathrm{TR}_{46}$-based CYP51A variants, with subsequent selection within these populations for resistance to fungicides belonging to other modes of actions in environments where multiple classes of fungicides are present. The presence of an azole sensitive isolate with carbendazim insensitivity can be explained by the rare emergence and survival of this strain in an environment with and without MBC fungicides, in the absence of azole fungicides or before azoles were introduced. Alternatively, this isolate could also be the offspring from a cross between a multi-fungicide resistant azole insensitive isolate and a wild-type strain.

High numbers of $A f$ colonies (up to 100 per bulb) were isolated from the tulip bulb samples when sampling the outer peels, which is in accordance with other studies investigating tulip and flower bulb samples $[23,24]$. The frequency of pan-azole resistant isolates was higher for the population isolated from tulip bulbs with 25 out of 108 isolates $(23.1 \%)$ detected in 2015 . The frequency was higher for bulbs purchased in the Netherlands $(36.7 \%, 22$ out of 60$)$ than for bulbs purchased in the UK $(6.3 \%$, three out of 48$)$, but the frequency for the UK-produced bulb population could be lower as it is likely that some purchased bulbs were directly imported from the Netherlands and not cultivated in the UK. No pan-azole resistant isolates were detected in populations sampled from Dutch tulip bulbs or UK daffodil bulbs in 2017, although the population size was smaller with 20 and 30 isolates, respectively. Seven out of the 25 pan-azole resistant isolates from the tulip bulb population carried $\mathrm{TR}_{46} / \mathrm{Y} 121 \mathrm{~F} / \mathrm{T} 289 \mathrm{~A}$ and were also highly insensitive to both carbendazim and pyraclostrobin. These seven isolates originated from different tulip bulb samples purchased in the Netherlands and the UK in 2015 and formed together with two Dutch tulip peel waste heap strains, isolated in 2018, and a Dutch environmental reference strain (TR46-NL), isolated before 2014, a cluster (cluster I in Figure 3) with an identical CSP type (t01), mating type (MAT1-1) and MLG (26-21-12-26-9-20-13.3-9-9), indicative for a clonal lineage [28]. The same MLG clone has also been widely reported for both clinical and environmental strains from the Netherlands in the past $[35,36]$, showing its spread and longevity through asexual reproduction. The successful expansion of this clone can be explained by a greater fitness in comparison with other genotypes. The presence of both $\beta$-tubulin F200Y and cytochrome $b$ G143A alleles, conferring resistance to MBC and QoI fungicides, respectively, will increase the chance of survival in environments where multiple modes of fungicides are used (bulb dipping, seed treatments and foliar sprays) or can be found (plant waste and compost heaps). One pan-azole resistant tulip bulb isolate carrying $\mathrm{TR}_{34} / \mathrm{L98H}$ (T11-8) was also insensitive to carbendazim and pyraclostrobin and can also be considered as a clonal lineage as strains with an identical MLG (14-20-9-31-9-10-8-10-28) have been reported in clinical and environmental strains from India and in environmental strains from Tanzania [36,38]. The successful rapid expansion of this clone in India can be explained by its multi-fungicide resistance status, the ability to outcompete other strains in the presence of MBC and/or QoI fungicides upon its arrival in India. However, the emergence of this strain in India through sexual recombination and subsequent spread to other continents cannot be ruled out [38]. In this context it would be interesting to see if the clonal expansion of a $\mathrm{TR}_{34}$ / L98H strain (MLG 22-10-9-9-9-23-8-10-8) reported in compost in 13 different cities in Iran can also be explained by the presence of additional fungicide 
resistant alleles in this clone [39]. The remaining 17 pan-azole resistant isolates were all sensitive to both carbendazim and pyraclostrobin. At least 11 of these carried $\mathrm{TR}_{34} / \mathrm{L} 98 \mathrm{H}$, from which at least eight were grouped together with a 2016 sugar beet field soil isolate from Belgium in cluster C, having an identical MLG (20-21-16-77-12-11-16.3-11-21), CSP t11 and MAT1-1 in common. As far as we know, this clone has not been reported before.

As expected, the highest frequency of pan-azole resistant isolates, $52.4 \%$, was detected in samples collected from tulip peel waste heaps with 22 out of 42 isolates detected. The frequency of pan-azole resistant strains in compost samples could not be determined as $A f$ isolates were mainly recovered from tebuconazole-amended agar due to excessive growth of other fungi on agar without addition of tebuconazole. High frequencies of up to $21.5 \%$ for recovery of pan-azole resistant strains from flower bulb waste heaps has also been reported in earlier studies [25]. Almost all pan-azole resistant strains (21 out of 22) were also highly insensitive to both carbendazim and pyraclostrobin, non-azole fungicides with different modes of action that are commonly found in tulip peel or flower waste heaps because of their application in bulb dipping and/or as part of foliar sprays to control diseases like Fusarium and Botrytis. Further evaluation of tulip peel waste heap and compost isolates showed that most multi-fungicide resistant isolates with high levels of voriconazole insensitivity (MIC value $>19.120 \mu \mathrm{g} / \mathrm{mL}$ ) carried $\mathrm{TR}_{46} / \mathrm{Y} 121 \mathrm{~F} / \mathrm{T} 289 \mathrm{~A}$, but a more complex CYP51A variant, $\mathrm{TR}_{34} / \mathrm{L98H} / \mathrm{T} 289 \mathrm{~A} / \mathrm{I364V} / \mathrm{G} 448 \mathrm{~S}$, was also detected in two isolates that were isolated from colonies growing on tebuconazole-amended agar (Table 2). This variant has been found in clinical strains from South Korea [40] and the UK since 2016 [41], but has also been reported in strains isolated from imported Dutch tulip bulbs in Japan in 2018 [24], and from compost heap samples in the UK in 2019 that were sampled as part of a citizen-science project [42]. The emergence of more complex variants over time shows similarities with the evolution of azole resistance in the plant pathogen Zymoseptoria tritici, where a stepwise accumulation of CYP51 mutations has resulted in adaptation to higher azole dose rates and/or new azoles with different binding properties entering the market [43].

The collection of clinical isolates used in this study showed a wide variety of fungicide sensitivity pheno- and genotypes that were also found in the environmental isolates. CYP51A variants $\mathrm{TR}_{34} / \mathrm{L} 98 \mathrm{H}, \mathrm{TR}_{34} / \mathrm{L} 98 \mathrm{H} / \mathrm{S} 297 \mathrm{~T} / \mathrm{F} 495 \mathrm{I}$ and $\mathrm{TR}_{46} / \mathrm{Y} 121 \mathrm{~F} / \mathrm{T} 289 \mathrm{~A}$, were detected in eight, four, eight and six isolates, respectively. The highest levels of insensitivity to voriconazole, imazalil and tebuconazole were generally measured for isolates carrying $\mathrm{TR}_{46} / \mathrm{Y121F} / \mathrm{T} 289 \mathrm{~A}$, while $\mathrm{TR}_{34}$ /L98H/S297T/F495I isolates were generally less sensitive to imazalil than $\mathrm{TR}_{34} / \mathrm{L} 98 \mathrm{H}$ isolates which can be explained by the presence of $\mathrm{F} 495 \mathrm{I}$, which particularly affects the binding of imidazoles such as prochloraz and imazalil [12]. Three out of the four $\mathrm{TR}_{34} / \mathrm{L} 98 \mathrm{H} / \mathrm{S} 297 \mathrm{~T} / \mathrm{F} 495 \mathrm{I}$ isolates carried beta-tubulin F200Y and were highly insensitive to the MBC fungicide carbendazim. All six TR ${ }_{46} / \mathrm{Y} 121 \mathrm{~F} / \mathrm{T} 289 \mathrm{~A}$ strains carried both beta-tubulin F200Y and cytochrome $b$ G143A alleles, the latter conferring high levels of insensitivity to the QoI fungicide pyraclostrobin. One $\mathrm{TR}_{46} / \mathrm{Y} 121 \mathrm{~F} / \mathrm{T} 289 \mathrm{~A}$ strain, CYP_15_38 with a rare CSP type t09, was also insensitive to boscalid, a SDHI fungicide, and carried SdhB H270Y. Two out of eight TR 34 /L98H isolates, ARAF017 and CYP_51_46, were also insensitive to all three non-azole fungicides carbendazim, pyraclostrobin and boscalid. One new fungicide resistant allele was detected, beta-tubulin E198A in isolate CYP_51_46, conferring resistance to carbendazim. This allele, like beta-tubulin F200Y, commonly found in plant pathogens that developed resistance to MBC fungicides [44], has recently been reported in Af [17].

STR Af typing of the clinical isolates revealed three additional clonal lineages. The German clinical isolate Asp 261, carrying TR 34 / L98H/S297T/F495I and beta-tubulin F200Y, shared an identical MLG (14-10-9-30-9-6-8-10-20) with clinical strain Afu_key29 reported in Denmark [12]. Two clinical TR $46 / Y 121 F / T 289 A$ isolates, V093-54 and CYP_15_7 from the Netherlands and Belgium, respectively, shared the same MLG (26-21-9-33-11-22-814-10), CSP type (t01) and mating type (MAT1-2) with the Dutch tulip field soil isolate STNL5-C8 and all three isolates carried beta-tubulin F200Y and cytochrome $b$ G143A alleles. 
Finally, tulip peel waste heap isolate TP UT5C-5 and clinical isolate OKH50, isolated in Japan in 2016, shared the same MLG (14-21-8-31-9-6-8-10-20) (cluster F in Figure 3) with an Irish clinical strain D5 isolated in 2015 [23], all carrying TR $_{34} /$ L98H. Traits like CSP t02 and MAT1-2 were shared between TP UT5C-5 and OKH50, but only TP UT5C-5 was highly insensitive to pyraclostrobin. This shows that pan-azole resistant clones of $A f$ can spread and develop de novo resistant alleles under exposure to different fungicides in hotspots. Using MLGs only based on STR $A f$ typing might underestimate the spread of clones as low levels of instability have recently been reported for markers $3 \mathrm{~A}$ and 3C. The recently reported MLG (14-21-8-32-9-6-8-10-20) for Chinese farm soil isolates carrying $\mathrm{TR}_{34} / \mathrm{L} 98 \mathrm{H}$ could also represent descendants of the same clone as OKH50 [45]. Whole genome sequencing and/or further typing using additional markers targeting hypervariable TRs within exons of surface protein coding genes will be needed to confirm this $[41,46]$.

\section{Conclusions}

The understanding of the emergence and epidemics of pan-azole resistant $A f$ over time has been improved by this and other recently published research linking strains found in patients with genotypes distributed in the wider environment [41,47]. The acquisition of azole-resistant alleles in clinical and/or environmental settings, as well as non-azole fungicide resistant alleles in the environment, have contributed to the rapid expansion of clonal lineages in hotspots under selection by fungicides, where sexual reproduction can also generate new genotypes with combinations of fungicide resistant alleles. Continuous real-time surveillance of aerosol samples at different locations for the presence of $A f$ combined with identification of CYP51A variants and other fungicide resistant alleles using a NGS genomics approach can provide information on the emergence and spatiotemporal dynamics of newly evolved strains. The detection of newly evolved azole resistant strains and clones can also be used to identify hotspots, where measures can be devised to reduce reproduction and/or fungicide selection pressure, aiming to minimize the risk of human exposure to airborne pan-azole resistant $A f$ conidia through inhalation. Strains carrying novel CYP51A variants, based on new mutations and or combinations of (new) mutations, as well as strains harboring different azole resistance mechanisms [48], should be tested against all available azole antifungals, as changes in their azole susceptibility status can guide decisions for an optimal diagnosis and management of aspergillosis in patients [49].

Supplementary Materials: The following are available online at https: / www.mdpi.com/article / 10.3390/microorganisms9112379/s1, Table S1: Isolates characterised using STRAf typing and sequence analysis of genes encoding CSP and CYP51A. Product sizes (bp) are presented for STRAf markers 2A, 2B, 2C, 3A, 3B, 3C, 4A, 4B and 4C.

Author Contributions: Conceptualization, B.A.F. and J.A.L.; methodology, S.L.A., S.J.H. and R.F.S.; investigation, S.L.A. and B.A.F.; data curation, S.L.A.; writing—original draft preparation, B.A.F.; writing-review and editing, R.F.S., J.S.W., J.A.L. and B.A.F.; project administration, B.A.F.; funding acquisition, B.A.F. All authors have read and agreed to the published version of the manuscript.

Funding: This research was funded by CropLife International, grant number 14209, and by the UK Natural Environment Research Council (NERC), grant number NE/P000940/1. The work at Rothamsted was part of the Smart Crop Protection (SCP) strategic programme (BBS/OS/CP/000001) funded through Biotechnology and Biological Sciences Research Council's Industry Strategy Challenge Fund.

Institutional Review Board Statement: Not applicable.

Informed Consent Statement: Not applicable.

Data Availability Statement: Data are available upon request. 
Acknowledgments: The authors are grateful to Matthew Fisher, Imperial College London, for providing the set of 18 clinical isolates as part of NERC funded projects NE/P001165/1 and NE/P000940/1 in 2019. We thank all members of the Scientific Advisory Board consisting of representatives of the Agrochemical Industry (Martin Semar (BASF), Klaus Stenzel and Andreas Goertz (Bayer CropScience), and Helge Sierotzki (Syngenta)) and experts from the Aspergillus fumigatus research community (Paul Verweij (Radboud University Medical Centre, The Netherlands), Paul Bowyer (University of Manchester), and Paul Dyer (University of Nottingham, UK)) for their valuable advice, support, and provision of samples during the project.

Conflicts of Interest: The authors declare no conflict of interest and the funders had no role in the design of the study; in the collection, analyses, or interpretation of data; in the writing of the manuscript, or in the decision to publish the results.

\section{References}

1. Denning, D.W.; Venkateswarlu, K.; Oakley, K.L.; Anderson, M.J.; Manning, N.J.; Stevens, D.A.; Warnock, D.W.; Kelly, S.L. Itraconazole resistance in Aspergillus fumigatus. Antimicrob. Agents Chemother. 1997, 41, 1364-1368. [CrossRef]

2. Snelders, E.; van der Lee, H.A.L.; Kuijpers, J.; Rijs, A.J.M.M.; Varga, J.; Samson, R.A.; Mellado, E.; Donders, A.R.T.; Melchers, W.J.G.; Verweij, P.E. Emergence of azole resistance in Aspergillus fumigatus and spread of a single resistance mechanism. PLoS Med. 2008, 5, e219. [CrossRef] [PubMed]

3. Howard, S.J.; Cerar, D.; Anderson, M.J.; Albarrag, A.; Fisher, M.C.; Pasqualotto, A.C.; Laverdiere, M.; Arendrup, M.C.; Perlin, D.S.; Denning, D.W. Frequency and evolution of azole resistance in Aspergillus fumigatus associated with treatment failure. Emerg. Infect. Dis. 2009, 15, 1068-1076. [CrossRef]

4. Lestrade, P.P.A.; Bentvelsen, R.; Schauwvlieghe, A.F.A.D.; Schalekamp, S.; van der Velden, W.J.F.M.; Kuiper, E.J.; van Paassen, J.; van der Hoven, B.; van der Lee, H.A.; Melchers, W.J.G.; et al. Voriconazole resistance and mortality in invasive aspergillosis: A multicentre retrospective cohort study. Clin. Infect. Dis. 2019, 68, 1463-1471. [CrossRef] [PubMed]

5. Fraczek, M.G.; Bromley, M.; Buied, A.; Moore, C.B.; Rajendran, R.; Rautemaa, R.; Ramage, G.; Denning, D.W.; Bowyer, P. The crd1B efflux transporter is associated with non-cyp51a-mediated itraconazole resistance in Aspergillus fumigatus. J. Antimicrob. Chemother. 2013, 68, 1486-1496. [CrossRef]

6. Hagiwara, D.; Arai, T.; Takahashi, H.; Kusuya, Y.; Watanabe, A.; Kamei, K. Non-cyp51A azole-resistant Aspergillus fumigatus isolates with mutation in HMG-CoA reductase. Emerg. Infect. Dis. 2018, 24, 1889-1897. [CrossRef] [PubMed]

7. Wei, X.; Chen, P.; Gao, R.; Li, Y.; Zhang, A.; Liu, F.; Lu, L. Screening and characterization of a non-cyp51A mutation in an Aspergillus fumigatus cox10 strain conferring azole resistance. Antimicrob. Agents Chemother. 2017, 61, e02101-16. [CrossRef]

8. Rivero-Menendez, O.; Alastruey-Izquierdo, A.; Mellado, E.; Cuenca-Estrella, M. Triazole Resistance in Aspergillus spp.: A Worldwide Problem? J. Fungi 2016, 2, 21. [CrossRef] [PubMed]

9. Berger, S.; Chazli, Y.E.; Babu, A.F.; Coste, A.T. Azole resistance in Aspergillus fumigatus: A consequence of antifungal use in agriculture? Front. Microbiol. 2017, 8, 1024. [CrossRef]

10. Lazzarini, C.; Esposto, M.C.; Prigitano, A.; Cogliati, M.; De Lorenzis, G.; Tortorano, A.M. Azole resistance in Aspergillus fumigatus clinical isolates from an Italian culture collection. Antimicrob. Agents Chemother. 2016, 60, 682-685. [CrossRef]

11. Lockhart, S.R.; Frade, J.P.; Etienne, K.A.; Pfaller, M.A.; Diekema, D.J.; Balajee, S.A. Azole resistance in Aspergillus fumigatus isolates from the ARTEMIS global surveillance study is primarily due to the TR/L98H mutation in the cyp51A gene. Antimicrob. Agents Chemother. 2011, 55, 4465-4468. [CrossRef]

12. Chen, Y.; Li, Z.; Han, X.; Tian, S.; Zhao, J.; Chen, F.; Su, X.; Zhao, J.; Zou, Z.; Gong, Y.; et al. Elevated MIC Values of Imidazole Drugs against Aspergillus fumigatus Isolates with TR 34 /L98H/S297T/F495I Mutation. Antimicrob. Agents Chemother. 2018, 62, e01549-17. [CrossRef]

13. Wiederhold, N.P.; Gil, V.G.; Gutierrez, F.; Lindner, J.R.; Albataineh, M.T.; McCarthy, D.I.; Sanders, C.; Fan, H.; Fothergill, A.W.; Sutton, D.A. First detection of $\mathrm{TR}_{34} \mathrm{~L} 98 \mathrm{H}$ and $\mathrm{TR}_{46}$ Y121F T289A cyp51 mutations in Aspergillus fumigatus isolates in the United States. J. Clin. Microbiol. 2016, 54, 168-171. [CrossRef]

14. Zhang, J.; Snelders, E.; Zwaan, B.J.; Schoustra, S.E.; Meis, J.F.; van Dijk, K.; Hagen, F.; van der Beek, M.T.; Kampinga, G.A.; Zoll, J.; et al. A novel environmental azole resistance mutation in Aspergillus fumigatus and a possible role of sexual reproduction in its emergence. MBio 2017, 8, e00791-17. [CrossRef] [PubMed]

15. Zhang, J.; Lopez Jimenez, L.; Snelders, E.; Debets, A.J.M.; Rietveld, A.G.; Zwaan, B.J.; Verweij, P.E.; Schoustra, S.E. 2021. Dynamics of Aspergillus fumigatus in azole fungicide-containing plant waste in the Netherlands (2016-2017). Appl. Environ. Microbiol. 2021, 87, e02295-20. [CrossRef] [PubMed]

16. Nakano, Y.; Tashiro, M.; Urano, R.; Kikuchi, M.; Ito, N.; Moriya, E.; Shirahige, T.; Mishima, M.; Takazono, T.; Miyazaki, T.; et al. Characteristics of azole-resistant Aspergillus fumigatus attached to agricultural products imported to Japan. J. Infect. Chemother. 2020, 26, 1021-1025. [CrossRef] [PubMed]

17. Fraaije, B.; Atkins, S.; Hanley, S.; Macdonald, A.; Lucas, J. The Multi-Fungicide Resistance Status of Aspergillus fumigatus Populations in Arable Soils and the Wider European Environment. Front. Microbiol. 2020, 11, 599233. [CrossRef] 
18. Kang, S.E.; Sumabat, L.G.; Melie, T.; Mangum, B.; Momany, M.; Brewer, M.T. Evidence for the agricultural origin of antimicrobial resistance in a fungal pathogen of humans. bioRxiv 2020. [CrossRef]

19. Gonzalez-Jimenez, I.; Garcia-Rubio, R.; Monzon, S.; Lucio, J.; Cuesta, I.; Mellado, E. 2021. Multiresistance to nonazole fungicides in Aspergillus fumigatus TR 34 /L98H azole-resistant isolates. Antimicrob. Agents Chemother. 2021, 65, e00642-21. [CrossRef]

20. Lemaire, B.; Normand, A.C.; Forel, J.M.; Cassir, N.; Piarroux, R.; Ranque, S. Hospitalized Patient as Source of Aspergillus fumigatus, 2015. Emerg. Infect. Dis. 2018, 24, 1524-1527. [CrossRef]

21. Engel, T.G.P.; Erren, E.; Van den Driessche, K.S.J.; Melchers, W.J.G.; Reijers, M.H.; Merkus, P.; Verweij, P.E. Aerosol Transmission of Aspergillus fumigatus in Cystic Fibrosis Patients in the Netherlands. Emerg. Infect. Dis. 2019, 25, 797-799. [CrossRef] [PubMed]

22. Verweij, P.E.; Lucas, J.A.; Arendrup, M.C.; Bowyer, P.; Brinkmann, A.J.F.; Denning, D.W.; Dyer, P.S.; Fisher, M.C.; Geenen, P.L.; Gisi, U.; et al. The one health problem of azole resistance in Aspergillus fumigatus: Current insights and future research agenda. Fungal Biol. Rev. 2020, 34, 202-214. [CrossRef]

23. Dunne, K.; Hagen, F.; Pomeroy, N.; Meis, J.F.; Rogers, T.R. Intercountry transfer of triazole-resistant Aspergillus fumigatus on plant bulbs. Clin. Infect. Dis. 2017, 65, 147-149. [CrossRef]

24. Hagiwara, D. Isolation of azole-resistant Aspergillus fumigatus from imported plant bulbs in Japan and the effect of fungicide treatment. J. Pestic. Sci. 2020, 45, 147-150. [CrossRef]

25. Schoustra, S.E.; Debets, A.J.M.; Rijs, A.J.M.M.; Zhang, J.; Snelders, E.; Leendertse, P.C.; Melchers, W.J.G.; Rietveld, A.G.; Zwaan, B.J.; Verweij, P.E. Environmental hotspots for azole resistance selection of Aspergillus fumigatus, the Netherlands. Emerg. Infect. Dis. 2019, 25, 1347-1353. [CrossRef] [PubMed]

26. Klaassen, C.H.W.; de Valk, H.A.; Balajee, S.A.; Meis, J.F.G.M. Utility of CSP typing to sub-type clinical Aspergillus fumigatus isolates and proposal for a new CSP type nomenclature. J. Microbiol. Methods 2009, 77, 292-296. [CrossRef]

27. De Valk, H.A.; Meis, J.F.G.M.; Curfs, I.M.; Muehlethaler, K.; Mouton, J.W.; Klaassen, C.H.W. Use of a novel panel of nine short tandem repeats for exact and high-resolution fingerprinting of Aspergillus fumigatus isolates. J. Clin. Microbiol. 2005, 43, 4112-4120. [CrossRef] [PubMed]

28. Sewell, T.R.; Zhu, J.; Rhodes, J.; Hagen, F.; Meis, J.F.; Fisher, M.C.; Jombart, T. Nonrandom distribution of azole resistance across the global population of Aspergillus fumigatus. MBio 2019, 10, e00392-19. [CrossRef]

29. Balajee, S.A.; Tay, S.T.; Lasker, B.A.; Hurst, S.F.; Rooney, A.P. Characterization of a novel gene for strain typing reveals substructuring of Aspergillus fumigatus across North America. Eukaryot. Cell 2007, 6, 1392-1399. [CrossRef]

30. De Groot, T.; Meis, J.F. Microsatellite stability in STR analysis Aspergillus fumigatus depends on number of repeat units. Front. Cell Infect. Microbiol. 2019, 9, 82. [CrossRef] [PubMed]

31. Peakall, R.; Smouse, P.E. GenAlEx 6.5: Genetic analysis in Excel. Population genetic software for teaching and research-an update. Bioinformatics 2012, 28, 2537-2539. [CrossRef]

32. Kamvar, Z.N.; Tabima, J.F.; Grünwald, N.J. Poppr: An R package for genetic analysis of populations with clonal, partially clonal, and/or sexual reproduction. PeerJ 2014, 2, e281. [CrossRef]

33. Bruvo, R.; Michiels, N.K.; D'Souza, T.G.; Schulenburg, H. A simple method for the calculation of microsatellite genotype distances irrespective of ploidy level. Mol. Ecol. 2004, 13, 2101-2106. [CrossRef] [PubMed]

34. Toyotome, T.; Hagiwara, D.; Kida, H.; Ogi, T.; Watanabe, A.; Wada, T.; Komatsu, R.; Kamei, K. First clinical isolation report of azole-resistant Aspergillus fumigatus with $\mathrm{TR}_{34} / \mathrm{L} 98 \mathrm{H}$-type mutation in Japan. J. Infect. Chemother. 2017, $23,579-581$. [CrossRef] [PubMed]

35. Lavergne, R.A.; Morio, F.; Favennec, L.; Dominique, S.; Meis, J.F.; Gargala, G.; Verweij, P.E.; Le Pape, P. First description of azole-resistant Aspergillus fumigatus due to $\mathrm{TR}_{46} / \mathrm{Y} 121 \mathrm{~F} / \mathrm{T} 289 \mathrm{~A}$ mutation in France. Antimicrob. Agents Chemother. 2015, 59, 4331-4335. [CrossRef] [PubMed]

36. Chowdhary, A.; Sharma, C.; van den Boom, M.; Yntema, J.B.; Hagen, F.; Verweij, P.E.; Meis, J.F. Multi-Azole-Resistant Aspergillus fumigatus in the Environment in Tanzania. J. Antimicrob. Chem. 2014, 69, 2979-2983. [CrossRef]

37. Fernández-Ortuño, D.; Torés, J.A.; de Vicente, A.; Pérez-García, A. Mechanisms of resistance to QoI fungicides in phytopathogenic fungi. Int. Microbiol. 2008, 11, 1-9. [PubMed]

38. Chowdhary, A.; Kathuria, S.; Xu, J.; Sharma, C.; Sundar, G.; Singh, P.K.; Gaur, S.N.; Hagen, F.; Klaassen, C.H.; Meis, J.F. Clonal expansion and emergence of environmental multiple-triazole-resistant Aspergillus fumigatus strains carrying the $\mathrm{TR}_{34} / \mathrm{L} 9 \mathrm{H}$ mutations in the cyp51A gene in India. PLoS ONE 2012, 7, e52871. [CrossRef]

39. Ahangarkani, F.; Badali, H.; Abbasi, K.; Nabili, M.; Khodavaisy, S.; de Groot, T.; Meis, J.F. Clonal Expansion of Environmental Triazole Resistant Aspergillus fumigatus in Iran. J. Fungi 2020, 6, 199. [CrossRef]

40. Cho, S.-Y.; Lee, D.-G.; Kim, W.-B.; Chun, H.-S.; Park, C.; Myong, J.-P.; Park, Y.-J.; Choi, J.-K.; Lee, H.-J.; Kim, S.-H.; et al. Epidemiology and antifungal susceptibility profile of Aspergillus species: Comparison between environmental and clinical isolates from patients with hematologic malignancies. J. Clin. Microbiol. 2019, 57, e02023-18. [CrossRef]

41. Rhodes, J.; Abdolrasouli, A.; Dunne, K.; Sewell, T.R.; Zhang, Y.; Ballard, E.; Brackin, A.P.; van Rhijn, N.; Tsitsopoulou, A.; Posso, R.B.; et al. Tracing patterns of evolution and acquisition of drug resistant Aspergillus fumigatus infection from the environment using population genomics. bioRxiv 2021. [CrossRef]

42. Shelton, J.M.G.; Collins, R.; Uzzell, C.B.; Alghamdi, A.; Dyer, P.S.; Singer, A.C.; Fisher, M.C. Citizen-science surveillance of triazole-resistant Aspergillus fumigatus in UK residential garden soils. bioRxiv 2021. [CrossRef] 
43. Cools, H.J.; Fraaije, B.A. Update on mechanisms of azole resistance in Mycosphaerella graminicola and implications for future control. Pest Manag. Sci. 2013, 69, 150-155. [CrossRef]

44. Koenraadt, H.; Somerville, S.C.; Jones, A.L. Characterisation of mutations in the $\beta$-tubulin gene of benomyl-resistant field strains of Venturia inaequalis and other plant pathogenic fungi. Phytopathology 1992, 82, 1348-1354. [CrossRef]

45. Chen, Y.; Dong, F.; Zhao, J.; Fan, H.; Qin, C.; Li, R.; Verweij, P.E.; Zheng, Y.; Han, L. High Azole Resistance in Aspergillus fumigatus Isolates from Strawberry Fields, China, 2018. Emerg. Infect. Dis. 2020, 26, 81-89. [CrossRef] [PubMed]

46. Garcia-Rubio, R.; Escribano, P.; Gomez, A.; Guinea, J.; Mellado, E. Comparison of Two Highly Discriminatory Typing Methods to Analyze Aspergillus fumigatus Azole Resistance. Front. Microbiol. 2018, 9, 1626. [CrossRef] [PubMed]

47. Rocchi, S.; Sewell, T.R.; Valot, B.; Godeau, C.; Laboissiere, A.; Millon, L.; Fisher, M.C. Molecular Epidemiology of Azole-Resistant Aspergillus fumigatus in France Shows Patient and Healthcare Links to Environmentally Occurring Genotypes. Front. Cell. Infect. Microbiol. 2021, 11, 729476. [CrossRef]

48. Fan, Y.; Wang, Y.; Korfanty, G.A.; Archer, M.; Xu, J. Genome-Wide Association Analysis for Triazole Resistance in Aspergillus fumigatus. Pathogens 2021, 10, 701. [CrossRef]

49. Slavin, M.A.; Chen, Y.C.; Cordonnier, C.; Cornely, O.A.; Cuenca-Estrella, M.; Donnelly, J.P.; Groll, A.H.; Lortholary, O.; Marty, F.M.; Nucci, M.; et al. When to change treatment of acute invasive aspergillosis: An expert viewpoint. J. Antimicrob. Chemother. 2021, dkab317. [CrossRef] 